\title{
A Multitracer Study of Radionuclides in Lake Zurich, Switzerland 1. Comparison of Atmospheric and Sedimentary Fluxes of ${ }^{7} \mathrm{Be},{ }^{10} \mathrm{Be},{ }^{210} \mathrm{~Pb},{ }^{210} \mathrm{Po}$, and ${ }^{137} \mathrm{Cs}$
}

\author{
C. Schuler, ${ }^{1}$ E.WIEland, ${ }^{23}$ P.H. SANTSChi, ${ }^{4}$ M. STURM, ${ }^{2}$ A. LueCK, ${ }^{2}$ S. BOllhalder, ${ }^{2}$ J. Beer, ${ }^{2}$ \\ G.BONANI, ${ }^{3}$ H.J. HOFMANN, ${ }^{3}$ M. SUTER, ${ }^{1}$ AND W. WOLFLI ${ }^{5}$
}

\begin{abstract}
Atmospheric and sedimentary fluxes of natural (i.e., ${ }^{210} \mathrm{~Pb},{ }^{210} \mathrm{Po},{ }^{7} \mathrm{Be}$, and ${ }^{10} \mathrm{Be}$ ) and artificial (i.e., Chernobyl ${ }^{137} \mathrm{Cs}$ ) radionuclides and particles through Lake Zurich (at $50 \mathrm{~m}$ and $130 \mathrm{~m}$ depth) between 1983 and 1987 were compared in order to establish trace metal pathways and their kinetics. Atmospheric fluxes

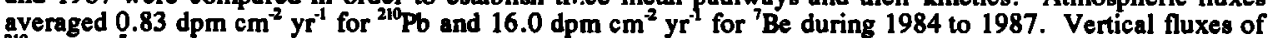
${ }^{210} \mathrm{~Pb}$ and ${ }^{\prime} \mathrm{Be}$, associated with settling particles, were measured in sediment traps deployed at $50 \mathrm{~m}$ and 130 $m$ depth at a station near the deepest part of Lake Zurich. Average fluxes of ${ }^{210} \mathrm{~Pb}$ and ${ }^{7} \mathrm{Be}$ at $50 \mathrm{~m}$ depth were 0.94 and $4.90 \mathrm{dpm} \mathrm{cm} \mathrm{yr}^{-1}$, respectively, and $16.5 \times 10^{7}$ atoms $\mathrm{m}^{-2} \mathrm{~d}^{-1}$ for ${ }^{10} \mathrm{Be}$. Sediment traps at $50 \mathrm{~m}$ quantitatively collected atmospherically deposited ${ }^{210} \mathrm{~Pb}$ falling through the water column. At $130 \mathrm{~m}$ depth, immediately above seasonally anoxic bottom waters, ${ }^{210} \mathrm{~Pb},{ }^{10} \mathrm{Be}$, and ${ }^{937} \mathrm{Cs}$ fluxes were higher than at $50 \mathrm{~m}$ by up to $60 \%$ at times during the summer stagnation period. Sediment inventories of ${ }^{20} \mathrm{~Pb}$ and ${ }^{10} \mathrm{Be}$ are in agreement with atmospheric nuclide fluxes, suggesting only moderate recycling of these nuclides in the bottom waters, whereas ${ }^{15} \mathrm{Cs}$ inventory in the sediments is lower than expected from sediment trap fluxes, indicating remobilization of this nuclide.
\end{abstract}

\section{INTRODUCTION}

Because of their defined input function, natural and man-made radionuclides make excellent tracers to study the geochemical cycling of elements in surface and groundwaters (for example, see the reviews in the work of Santschi and Honeyman [1989] and Murray [1987]).

The radiotracer methodology has firmly established itself in the marine sciences for the study of mechanisms and rates of processes which control the movement in the water of soluble and particulate trace elements over varying time scales [Broecker and Peng, 1982]. In the limnological sciences, it has become a promising but not yet established tool. However, even though lakes and oceans are similar in some respects, there are also important differences. These arise from the fact that lakes are often more dynamic and more variable than the oceans, thus giving rise to more rapidly changing radionuclide and trace element concentrations in the water. Furthermore, generalizations are often more difficult as different factors such as boundary effects, geographic location, hydrography, or trophic status play an important role in the removal process as well.

A small number of investigators, however, have studied the seasonal cycling of radionuclides in lakes in order to use information on residence times and transport pathways in the investigations of in-lake processes as well as boundary effects. For example, Barnes et al. [1979], Appel [1982], Barth [1984], Talbot and Andren [1984], Stiller and Imboden [1986],

\footnotetext{
'Swiss Federal Institute of Water Resources and Water Pollution Control (EAWAG), Dubendorf, Switzerland

'Institut fur Mittel-energiephysik, ETH Honggerberg, Zurich, Switzerland.

${ }^{3}$ Now at Department of Civil Engineering, Stanford University, Stanford, CA.

'Department of Marine Sciences, Texas A \& M University, Galveston.

'Paul Scherrer Institut, Villigen, Switzerland.
}

Copyright 1991 by the American Geophysical Union.

Paper number 91JC01765.

$0148-0227 / 91 / 91 \mathrm{JC}-01765 \$ 05.00$
Benoit and Hemond [1986], and Mangini et al. [1990] used

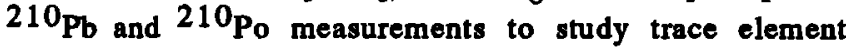
residence times in lakes as they are affected by boundary processes. Robbins and Eadie [1982], Schiff et al. [1983], and Hawley et al. [1986] used the short-lived $7_{\mathrm{Be}}$ while the group of Edgington, Robbins, and Eadie (for example, see the review of Eadie and Robbins [1987]) used also some fallout radionuclides in the Great Lakes for the same purpose. The purposeful tracer studies of the group of Broecker, Hesslein, Schindler, Emerson, and Santschi allowed similar studies in the Canadian Shield lakes [e.g., Hesslein et al., 1980; Hesslein, 1987; Santschi et al., 1986, and references therein]. Whereas 10 Be has recently been analysed on marine particles [Sharma et al., 1987], we present here for the first time measurements of ${ }^{10} \mathrm{Be}$ concentrations on lacustrine particles.

We present this five-year radiotracer study in two parts. In the first part, vertical fluxes from the atmosphere into the lake and from the lake water to their final repositories, the sediments, are discussed. The aim of this first paper is to establish vertical scavenging efficiencies of transfer from the atmosphere through the lake water into the sediments and to elucidate seasonal controls of radionuclide scavenging. For this purpose, efficient and reliable collectors of vertical fluxes were needed as well as independent means for assessing their accuracy. Another purpose was to investigate the relationships between radioactive ${ }^{210} \mathrm{~Pb}$ and stable $\mathrm{Pb}$ in Lake Zurich, as their input functions into the environment as well as their chemical form are different [Salomons and Förstner, 1984].

In the second part, we will discuss the importance of boundary effects on radionuclide behavior in the interior of a lake and present a conceptual and mathematical model for assessing particle dynamics. Ratios of radionuclide fluxes are used to test the model and to assess the magnitude of boundary effects [Wieland et al., this issue].

The nuclides investigated are ${ }^{10} \mathrm{Be}$ and ${ }^{7} \mathrm{Be}$ (cosmogenic origin, half-life of $1.5 \times 10^{6}$ years and 53 days, respectively), $210 \mathrm{~Pb}$ (produced by radioactive decay of the soil-derived noble gas $222 \mathrm{Rn}$ in the atmosphere, half-life of 22 years), Chernobyl ${ }^{137} \mathrm{Cs}$ (half-life of 30 years), and ${ }^{210} \mathrm{Po}$ (from 
$210 \mathrm{~Pb}$ decay, half-life of 138 days) as near-ideal tracers with quantifiable input functions. We will show that atmospheric precipitation is the most prominent input term for many particle-reactive trace elements and radionuclides (e.g., cosmogenic and radon-produced nuclides). River inputs of these nuclides are negligible for Lake Zurich, because of the presence of two upper lying lakes which remove particles and particle-reactive trace metals and nuclides from the water before they can enter the lower part of Lake Zurich [Santschi tt al., 1990].

In situ production of ${ }^{210} \mathrm{~Pb}$ in lakes with similar mean depth and climate as those of Lake Zurich is generally insignificant [Stiller and Imboden, 1986]. This can be shown as follows. According to D.M. Imboden (personal communication, 1990), ${ }^{222} \mathrm{Rn}$ concentrations in near-bottom waters of Lake Zurich are very low, despite a relatively high measured potential production rate in the sediments. Expected fluxes of ${ }^{222} \mathrm{Rn}$ are about $300 \mathrm{dpm} \mathrm{m} \mathrm{m}^{-2} \mathrm{~d}^{-1}$ which correspond to a calculated surface water concentration of about $6 \times 10^{-5} \mathrm{dpm} \mathrm{L}^{-1}$. The calculation assumes a ratio of water volume in the top $0-10 \mathrm{~m}$ of the water column to surface area of boundary sediments of about $50 \mathrm{~m}$. Since the water residence time in the mixed layer is certainly less than the 1-year average water residence time of the lake, the ${ }^{210} \mathrm{~Pb}$ production from ${ }^{222} \mathrm{Rn}$ decay can be calculated by $\left[{ }^{210} \mathrm{~Pb}\right]=\left[{ }^{222} \mathrm{Rn}\right] \times\left(1-\exp \left(-\lambda_{\mathrm{Pb}} \Delta \mathrm{t}\right)\right) \leq 10^{-3} \mathrm{dpm} \mathrm{L}{ }^{-1}$ which is significantly smaller than the measured activity of $10^{-2} \mathrm{dpm}$ $\mathrm{L}^{-1}$ of ${ }^{210} \mathrm{~Pb}$ in the water.

\section{STUDY SITE}

Lake Zurich is $\mathrm{U}$-shaped in cross section and has steep lateral slopes on two sides (east, west) but gentle slopes on the south and north side. The lake is divided by a dam into two basins, the Upper Lake and the Lower Lake. The major inlet into Lake Zurich is the Linth River connecting Lake Walen and the Upper Lake, and the majority of the allochthonous material of the river input is deposited in these two preceding lakes. Therefore, lower Lake Zurich which, as the major basin of this lake, is relatively free of riverine sediment inputs during most of the year except in the winter. This feature makes this lake ideal for observing in-lake processes. The lower basin of Lake Zurich has a surface area of $67.3 \mathrm{~km}^{2}$, a volume of $3.4 \mathrm{~km}^{3}$, and a drainage basin of $1829 \mathrm{~km}^{2}$. Its maximum depth and average depth are $137 \mathrm{~m}$ and $49 \mathrm{~m}$, respectively. Lake Zurich is stratified between April and October, with the thermocline varying between a depth of $10 \mathrm{~m}$ and a depth of $15 \mathrm{~m}$. The deepest water layer below $130 \mathrm{~m}$ becomes anoxic during summertime. Settling material between $50 \mathrm{~m}$ and $130 \mathrm{~m}$ is composed of organic $\mathrm{C}(14-60 \%), \mathrm{CaCO}_{3}(20-60 \%), \mathrm{MgCO}_{3}$ (1-3\%), $\mathrm{Fe}_{2} \mathrm{O}_{3}(0.2-2 \%), \mathrm{MnO}_{2}(0.1-16 \%)$ and silicates (0.540\%) [Sigg et al., 1987]. Sediment traps were deployed at a station near the deepest part of the lake at depths of $50 \mathrm{~m}$ and $130 \mathrm{~m}$ to collect the particle flux through the water column.

\section{METHODs}

Samples of rainwater obtained from collectors of atmospheric precipitation on the roof of the Swiss Federal Institute of Water Resources and Water Pollution Control (EAWAG) (13 km away from the lake) [Santschi et al., 1988], sediments from collectors of the particle rain in the lake (sediment traps) [Bloesch and Sturm, 1986; Sigg et al., 1987] and from in situ filtration and extraction $(-700 \mathrm{~L}$ in $2-6$ hours) [Bishop et al., 1985], or water $(100 \mathrm{~L})$ pumped from different depths in the lake, were taken to the laboratory.

The collection methods of settling particles in aquatic systems have recently been reviewed [e.g., Butman, 1986; Knauer et al., 1984]. Artifacts can be caused by hydrodynamic effects, which can bias collection efficiencies, and by zooplankton grazing and capture. In lakes below the thermocline, current velocities are usually below a few centimeters per second [Lemmin and Imboden, 1987], and therefore one would expect the hydrodynamic artifacts to be minimal. Zooplankton grazing can cause trace element loss to solution as well as extra gain of particulate matter in the collection cups. The reliability of the vertical flux measurements therefore needs to be assessed independently. Atmospherically delivered radionuclides are ideal for this purpose.

The problems of atmospheric collectors are discussed by Dasch [1985]. Since we were mostly interested in measuring deposition rates onto a water surface, a cylindrical collector which had some acidified water on the bottom and which was set up on the rooftop of the laboratory building (EAWAG) was used. The collection efficiency of our atmospheric collectors is probably within $100 \pm 10 \%$ [Santschi et al., 1988], as judged from comparison of the fluxes of various Chernobyl radionuclides in collectors of different positions and geometry, as well as from inventories in grass 3-4 days after fallout [Santschi et al., 1987, 1988]. Rain or water samples were acidified with $\mathrm{HCl}$ to $\mathrm{pH}=1$. $\mathrm{FeCl}_{3}$ and appropriate yield tracers and carriers (e.g., ${ }^{208} \mathrm{Po}$, stable $\mathrm{Pb}$ and $\mathrm{Be}$ ) were added in order to determine procedural yields. After a suitable time of the order of 1 day, $\mathrm{Fe}(\mathrm{OH})_{3}$ was precipitated by adding $\mathrm{NH}_{4} \mathrm{OH}$ and was separated. Merck analytical reagent grade chemicals were used to minimize blank effects.

Sediment traps with diameters of $20 \mathrm{~cm}$ and lengths of 100 $\mathrm{cm}$, deployed in duplicates, collected between 0.1 and several grams of settling particles within the 14 to 21 days of exposition. No poison was added to these traps in order to avoid contamination. Zooplankton feeding on material collected in these traps was judged not to be a serious problem due to the low temperature (i.e., $\leq 6^{\circ} \mathrm{C}$ ), light and productivity levels at depths of $50 \mathrm{~m}$ and below [Sigg et al., 1987]. Sediment trap samples were directly gamma-counted in the same vial type, after they were concentrated by freeze-drying. The dry weight was corrected for contribution of dissolved salts resulting from freeze-drying of supernatent water. All manipulations of the particles were carried out in a laminar flow hood. A gravity corer with polyvinylchloride (PVC) tubes was used to collect sediment samples.

The sediment core was taken in 1987 at $130 \mathrm{~m}$ water depth, dissected in $0.6-$ to $1.2-\mathrm{cm}$ intervals within a few hours after collection, dried at $60^{\circ} \mathrm{C}$, weighted, and homogenized before non destructive gamma ray spectroscopy and further chemical analysis. Dry weights were determined from aliquots of fresh sediment samples.

$\mathrm{Fe}(\mathrm{OH}) 3$ precipitates, freeze-dried particles and dried sediment samples were gamma-counted on a high purity Ge well detector coupled to a Canberra S-90 multichannel analyzer and PDP II$23+$ computer in order to measure ${ }^{7} \mathrm{Be}(478 \mathrm{keV}),{ }^{210} \mathrm{~Pb}$ (46 $\mathrm{keV})$ and ${ }^{137} \mathrm{Cs}(661 \mathrm{keV})$. Results were corrected for radioactive decay, ingrowth and yield of extraction using the recoveries of $\mathrm{Pb}$ and $\mathrm{Be}$ in the final $\mathrm{Fe}(\mathrm{OH})_{3}$ precipitate, determined by atomic absorption spectrometry. High purity $\mathrm{Ge}$ 
well detector geometries were calibrated with standards of the appropriate radionuclide (obtained from New England Nuclear Corporation and Amersham Corporation) in order to circumvent summation corrections. Polonium 210 (and also $210^{\mathrm{Pb}}$ via ${ }^{210} \mathrm{Po}$ ingrowth) was measured by alpha counting after proper chemical separation [Santschi et al., 1979, 1980] by using isotope dilution methodology. Measured nuclide activities determined by gamma counting were calculated by comparing them to standard solutions of the same nuclide in the same geometry. Standards of ${ }^{208}$ Po (for example, from Amersham Corporation; Health and Safety Laboratory, New York, or courtesy of J. Dominik, University of Geneva, "Goodbye" standard) were calibrated against $210_{\mathrm{Pb}}$ solutions supplied from Amersham Corporation and Environmental Protection Agency Laboratories; standard solutions of ${ }^{7} \mathrm{Be}$ were supplied from Laboratoire de Meteorologie des Rayonements Ionisants, Gif-sur-Ivette, France and ${ }^{137}$ Cs was supplied by New England Nuclear Corporation, Dreieich, Germany. Activity measurements are given in units of decays per minute (60 dpm $=1 \mathrm{~Bq})$.

The ${ }^{10} \mathrm{Be}$ measurements were carried out at the Swiss Federal Institute of Technology/Paul Scherrer Institute (ETH/PSI) accelerator mass spectometry (AMS) facility in Zurich [Suter et al., 1984]. Samples of trapped material (approximately 0.3$0.6 \mathrm{~g})$ were spiked with $0.5 \mathrm{mg}{ }^{9} \mathrm{Be}$ carrier, subsequently dissolved in $3 \mathrm{~mL}$ concentrated $\mathrm{HCl}$, and mixed with $2 \mathrm{~mL}$ of $25 \% \mathrm{H}_{2} \mathrm{O}_{2}$. Then, suspensions were carefully heated up by $\mathbb{R}$ lamps in order to enhance decomposition of organic matter. Within half an hour, $\mathrm{CO}_{2}$ release was completed, and the suspensions were agitated ultrasonically for 1 hour. After centrifuging (10 min at $4000 \mathrm{rpm}$ ), solutions were transferred into 50 - $\mathrm{mL}$ beakers. The residual matter was again resuspended in $6 \mathrm{M} \mathrm{HCl}$, agitated ultrasonically for $10 \mathrm{~min}$ and centrifuged. A $p H$ of -2.5 was set by adding $10 M \mathrm{NaOH}$ to combined solutions. After adding $0.5 \mathrm{~mL} 10 \%$ Ethylene Diamine Tetra Acetate (EDTA) solution, the $\mathrm{pH}$ was raised to 9.5 using concentrated $\mathrm{NH}_{4} \mathrm{OH}$. Solutions were equilibrated overnight and then centrifuged. The white-reddish precipitate was washed several times by resuspending it in $14 M \mathrm{NaOH}$ and by subsequently centrifuging suspensions (10 min at $4000 \mathrm{rpm}$ ) in order to reduce the amount of slightly soluble hydroxides (eg., $\mathrm{Fe}(\mathrm{OH})_{3}$ ). The residual, mainly Be hydroxide, was washed

with distilled water, dried at $60^{\circ} \mathrm{C}$ for 24 hours, and converted to $\mathrm{BeO}$ by ignition at $950^{\circ} \mathrm{C}$ in a quartz crucible [Beer et al., $1983]$.

\section{ResUlts aND Discussion}

\section{Atmospheric Input Functions}

Atmospheric fluxes of ${ }^{7} \mathrm{Be}$ and ${ }^{210} \mathrm{~Pb}$ are shown in Figures $1 a$ and $1 b$. The most striking features are the pronounced flux maxima in July/August for both ${ }^{7} \mathrm{Be}$ and ${ }^{210_{\mathrm{Pb}}}$ nuclides, indicating a similar seasonality of the input functions of both nuclides. This similarity is further documented in Figure $1 c$ by the close correlation of the two fluxes extending over 4 years. The correlation coefficient, $R$, for the correlation of $210_{\mathrm{Pb}}$ versus ${ }^{7}$ Be fluxes is 0.90 (with $N=22$, this is significant at the 99.9\% confidence level). Both nuclides also correlate closely with air temperature ( $r=0.69$ and 0.78 for ${ }^{210} \mathrm{~Pb}$ and ${ }^{7} \mathrm{Be}$, respectively) but not with rainfall (Table 5). The close correlation of atmospheric ${ }^{210} \mathrm{~Pb}$ fluxes and air temperature indicates the seasonality of the two parameters. It might indicate the temperature control of the flux of ${ }^{222} \mathrm{Rn}$ out of soils, which is also controlled by humidity. If we assume that mixing of stratospheric ${ }^{7} \mathrm{Be}$ into the troposphere is occurring in late spring, the summer maxima of atmospheric ${ }^{7} \mathrm{Be}$ flux most likely reflect seasonal control of deposition by atmospheric precipitation (e.g., summer thunderstorms) and scavenging processes. Concurrent maxima in atmospheric deposition rates of ${ }^{210} \mathrm{~Pb}$ and ${ }^{7} \mathrm{Be}$ have also been reported by Dominik et al. [1987], Olsen et al. [1985, 1986], and Matsunami et al. [1979]. However, their flux maxima occurred, as expected, in springtime.

Atmospheric fluxes of ${ }^{134} \mathrm{Cs}$ and ${ }^{137} \mathrm{Cs}$ were taken from Santschi et al. $[1988,1990]$ as $4.5 \mathrm{kBq} \mathrm{m} \mathrm{m}^{-2}$, deposited between April 30 and May 8, 1986. The initial ${ }^{134} \mathrm{Cs} /{ }^{137} \mathrm{Cs}$ ratio was $0.50 \pm 0.03$.

The average ${ }^{7} \mathrm{Be}$ flux during the years $1984-1987$ (16.0 dpm $\mathrm{cm}^{-2} \mathrm{yr}^{-1}$ at $\sim 110 \mathrm{~cm} \mathrm{yr}^{-1}$ rainfall; see Table 1) agrees well with that measured in atmospheric collectors on the shores of Lake Geneva in the western part of Switzerland, i.e., $16.5 \mathrm{dpm}$ $\mathrm{cm}^{-2} \mathrm{yr}^{-1}$ (at $120 \mathrm{~cm} \mathrm{yr}^{-1}$ rainfall [Dominik et al., 1987]) and $15.9 \mathrm{dpm} \mathrm{cm}^{-2} \mathrm{yr}^{-1}$ calculated for this latitude band from average atmospheric concentrations of ${ }^{7} \mathrm{Be}$ of $0.18 \mathrm{dpm} \mathrm{m}$ [Kommission zur Ueberwachung der Radioaktivität (KUER), 1982] and transfer velocities of $2.8 \mathrm{~cm} \mathrm{~s}^{-1}$ [Turekian et al., 1983]. Our average ${ }^{210} \mathrm{~Pb}$ flux for the years $1984-1987$ is 0.83 $\mathrm{dpm} \mathrm{cm}^{-2} \mathrm{yr}^{-1}$ (Table 1), again close to the value determined by Dominik et al. [1987] for the westem part of Switzerland $\left(0.91 \mathrm{dpm} \mathrm{cm} \mathrm{cr}^{-2} \mathrm{yr}^{-1}\right)$ and the value of $0.83 \mathrm{dpm} \mathrm{cm}^{-2} \mathrm{yr}^{-1}$ expected from the average atmospheric concentration of 0.026 $\mathrm{dpm} \mathrm{m}^{-3}$ [KUER, 1982] and the transfer velocity of $0.95 \mathrm{~cm}$ $\mathrm{s}^{-1}$ [Turekian et al., 1983].

During 1987, total atmospheric deposition of ${ }^{10} \mathrm{Be}$ and ${ }^{7} \mathrm{Be}$ averaged to $5.0 \pm 2.2 \times 10^{7}$ and $2.9 \pm 1.4 \times 10^{7}$ atoms $\mathrm{m}^{-2} \mathrm{~d}^{-1}$, respectively (total rainfall: $110 \mathrm{~cm} \mathrm{yr}^{-1}$ ). Deposition fluxes are higher in summer $\left({ }^{7} \mathrm{Be}: 3.7 \pm 1.1 \times 10^{7}\right.$ atoms $\mathrm{m}^{-2}$ $\mathrm{d}^{-1},{ }^{10} \mathrm{Be:} 6.1 \pm 2.5 \times 10^{7}$ atoms $\left.\mathrm{m}^{-2} \mathrm{~d}^{-1}\right)$ than in winter $\left({ }^{7} \mathrm{Be}\right.$ : $1.4 \times 10^{7}$ atoms $\mathrm{m}^{-2} \mathrm{~d}^{-1}, 10_{\mathrm{Be}} 2.9 \times 10^{7}$ atoms $\mathrm{m}^{-2} \mathrm{~d}^{-1}$ ). Atmospheric ${ }^{7} \mathrm{Be}$ and ${ }^{10} \mathrm{Be}$ fluxes measured in the western part of Switzerland (Berne) during 1980-1985 by Luder [1986] were $3.0 \pm 0.3 \times 10^{7}$ atoms $\mathrm{m}^{-2} \mathrm{~d}^{-1}$ for ${ }^{7} \mathrm{Be}$ and $8.0 \pm 1.2 \times 10^{7}$ atoms $\mathrm{m}^{-2} \mathrm{~d}^{-1}$ for ${ }^{10} \mathrm{Be}$ (total rainfall: $103 \mathrm{~cm} \mathrm{yr}^{-1}$ ).

Since ${ }^{10} \mathrm{Be}$ and ${ }^{7} \mathrm{Be}$ are produced by cosmic rays with a constant ratio of about 0.5 in the atmosphere, the ratio ${ }^{10} \mathrm{Be} /{ }^{7} \mathrm{Be}$ represents an ideal chronometer for transport processes [Raisbeck et al., 1981]. The annual ${ }^{10} \mathrm{Be} /{ }^{7} \mathrm{Be}$ ratio measured in atmospheric deposition was $1.86 \pm 0.62$ in Dibendorf and $2.48 \pm 0.32$ in the western part of Switzerland [Luder, 1986] . This ratio is higher than the production ration due to radioactive decay of ${ }^{7} \mathrm{Be}$ in the atmosphere.

Vertical Fluxes of Particles and Radionuclides in Sediment Traps

Sediment trap samples were collected between 1983 and 1987 in Lake Zurich in order to determine particle as well as isotope fluxes ( ${ }^{7} \mathrm{Be},{ }^{10} \mathrm{Be},{ }^{137} \mathrm{Cs}$, and ${ }^{210} \mathrm{~Pb}$ ).

Average sediment trap fluxes of particles, ${ }^{7} \mathrm{Be}$, and ${ }^{210} \mathrm{~Pb}$ in both sediment traps were calculated for summer and winter periods between 1983 and 1987 and are listed in Table 2. Errors 

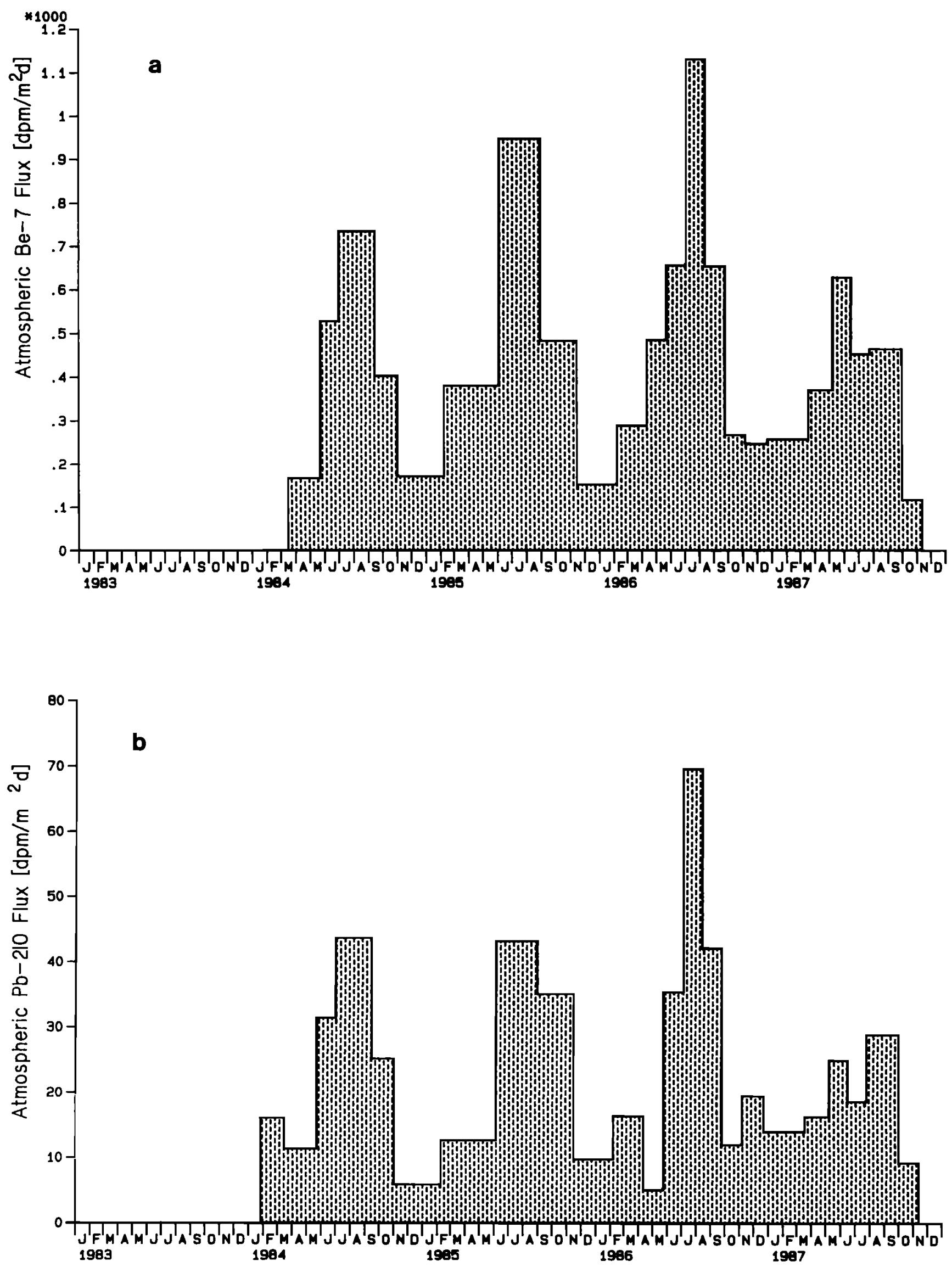

Fig. 1. Atmospheric fluxes of (a) ${ }^{7} \mathrm{Be}$ and (b) ${ }^{210} \mathrm{~Pb}$ as a function of time measured at Dibendorf between 1983 and 1987. (c) Also shown is the correlation of atmospheric ${ }^{7} \mathrm{Be}$ and ${ }^{210} \mathrm{~Pb}$. Typical error bars are given as examples. 


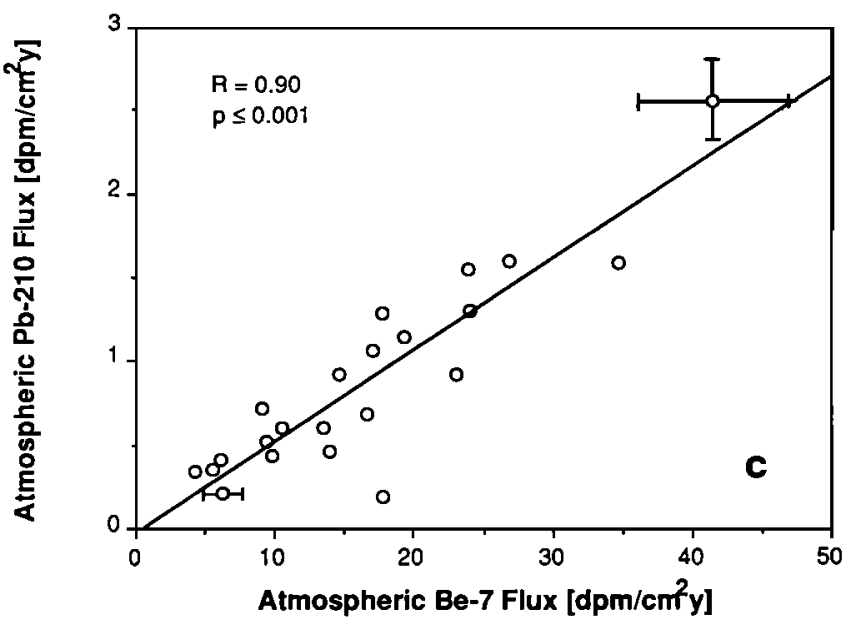

Fig. 1. (continued) of $1.65 \mathrm{~s}$ (95\% confidence limits) in particle fluxes are estimated to $\pm 10 \%$. Errors in radionuclide fluxes are estimated from errors in particle flux measurements and an additional $1.65 \sigma$ counting error of generally $\leq 5 \%$.

Particle fluxes and fluxes of particle-bound ${ }^{210} \mathrm{~Pb},{ }^{7} \mathrm{Be}$, and ${ }^{137} \mathrm{Cs}$ out of the water column, measured at $50 \mathrm{~m}$ and $130 \mathrm{~m}$ depth, are depicted in Figures $2 a-2 d$, and those of ${ }^{10} \mathrm{Be}$ are shown in Figure 5. Maximum fluxes of ${ }^{7} \mathrm{Be}$ and ${ }^{210} \mathrm{~Pb}$ are observed in the summer months (July-August) during peaks in primary production and atmospheric deposition of radionuclides. Minimum fluxes were found in the winter season. This strong seasonality is documented also by the significant correlation of ${ }^{7} \mathrm{Be}$ and ${ }^{210} \mathrm{~Pb}$ fluxes in the upper water column with water temperature (Table 5). Temperature here is likely a surrogate parameter for light intensity which partially controls primary productivity and, hence, the removal rates of particles which are responsible for radionuclide scavenging.

TABLE 1. Radionuctide Faxes in Lale Zarich

\begin{tabular}{|c|c|c|c|c|c|}
\hline \multirow[b]{2}{*}{ Tirse Interval } & \multicolumn{3}{|c|}{ Atmognteric Dinxe: } & \multicolumn{2}{|c|}{ Snndine Crop in I sk Wrine } \\
\hline & $\begin{array}{c}210 \mathrm{~Pb}, \mathrm{dpm} \mathrm{cm}^{-2} \mathrm{y}^{-1} \\
( \pm S 10 \%)\end{array}$ & 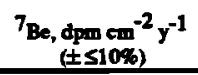 & $\begin{array}{l}{ }_{\mathrm{Be}} /^{210_{\mathrm{Pb}}} \\
( \pm \leq 10 \%)\end{array}$ & $\begin{array}{c}210 \mathrm{Fb}, \text { dpm cm } \\
( \pm \leq 158)\end{array}$ & $\begin{array}{c}{ }^{7} \mathrm{Be}, \mathrm{dpm} \mathrm{cm}^{-2} \\
( \pm<15 \%)\end{array}$ \\
\hline $\begin{array}{l}\text { Summer } 1983 \\
\text { Winter } 1983 / 1984 \\
\text { Summer } 1984 \\
\text { Winter } 1984 / 1985 \\
\text { Winter } 1985 / 1986 \\
\text { Summer } 1986 \\
\text { Winter } 1986 / 1987 \\
\text { Summer } 1987 \\
\text { Winter } 1987 \\
1983-1987 \text { average } \\
\text { Summer average } \\
\text { Winter average } \\
1984 \text { average } \\
1985 \text { average } \\
1986 \text { avernge } \\
1987 \text { average }\end{array}$ & $\begin{array}{l}0.59 \\
1.07 \\
0.45 \\
0.47 \\
1.39 \\
0.55 \\
0.84 \\
0.34 \\
0.83 \\
1.08 \\
0.48 \\
0.96 \\
0.82 \\
0.88 \\
0.69\end{array}$ & \begin{tabular}{r|}
9.1 \\
17.7 \\
9.0 \\
7.7 \\
26.7 \\
9.4 \\
17.3 \\
4.3 \\
16.0 \\
20.8 \\
7.9 \\
17.1 \\
17.6 \\
16.0 \\
13.5
\end{tabular} & $\begin{array}{l}15.4 \\
16.5 \\
20.7 \\
16.4 \\
19.2 \\
17.1 \\
20.6 \\
12.7 \\
19.3 \\
19.3 \\
16.5 \\
17.8 \\
21.5 \\
18.2 \\
19.6\end{array}$ & $\begin{array}{l}0.075 \pm 0.07 \\
0.10 \\
0.05\end{array}$ & $\begin{array}{l}1.77 \pm 0.11 \\
1.75 \\
1.80\end{array}$ \\
\hline
\end{tabular}

Timo-weighted mean values are given. Erom indicated are 1.65 o.

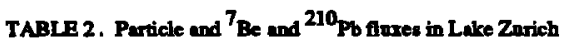

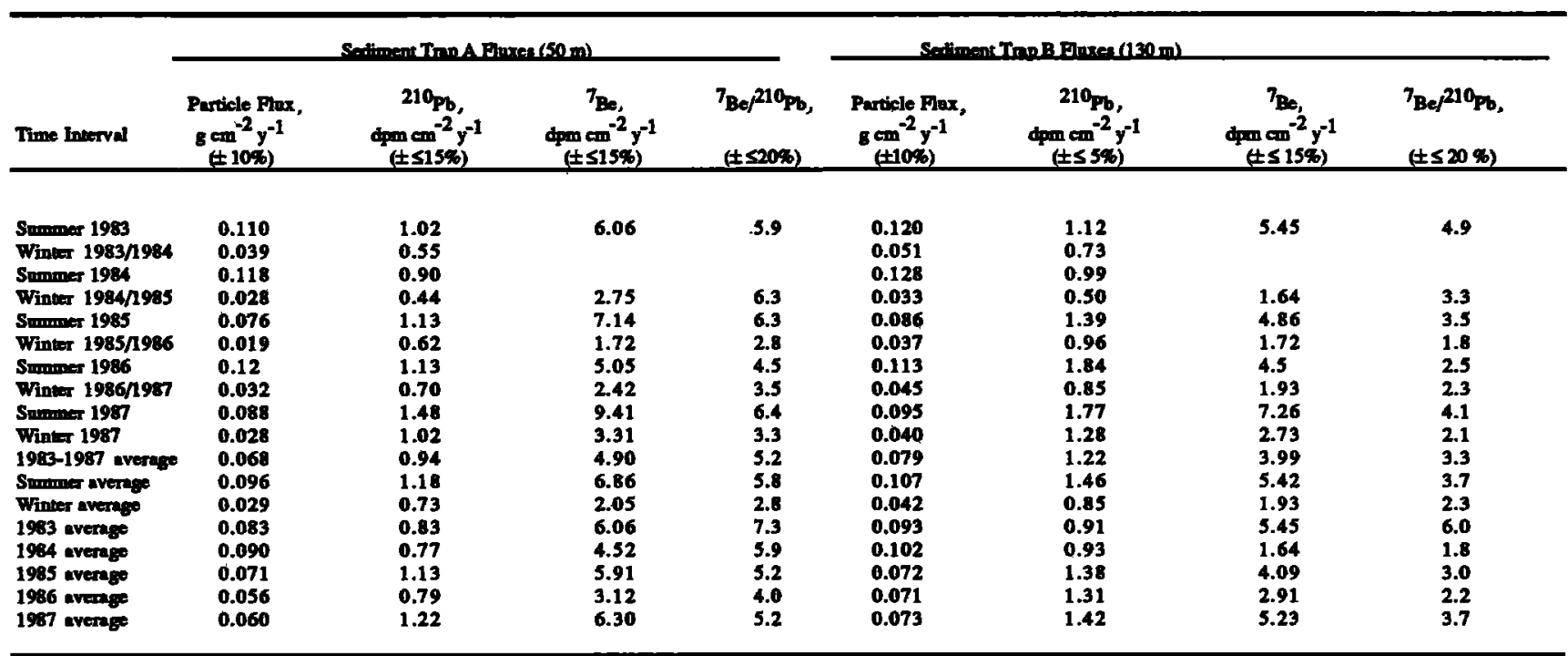


A striking feature of Figures $2 a, 2 c$ and $2 d$ is the enhancement in ${ }^{210} \mathrm{~Pb}$ and ${ }^{137} \mathrm{Cs}$ fluxes and, to a lesser extent, particle fluxes at the bottom of the lake (sediment trap deployed at $\mathbf{1 3 0}$ $m$ depth) as compared to those in the sediment trap at $50 \mathrm{~m}$, which probably indicates horizontal transport processes of fine, flocculent particles enriched in trace metals and radionuclides [Santschi, 1989; Schuler et al., 1987]. Irrespective of the various transfer and scavenging processes,
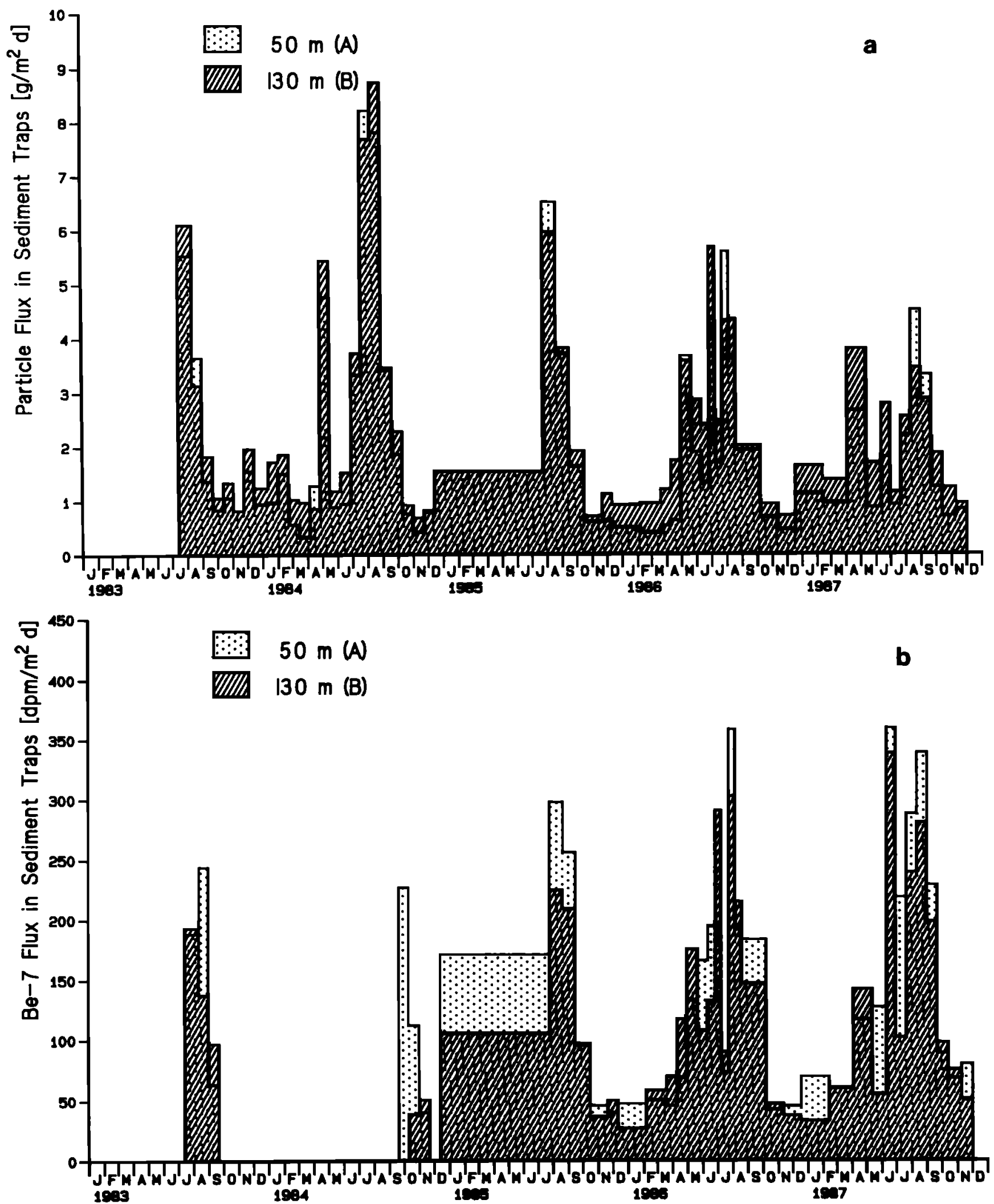

Fig. 2. Time wries of (a) particle, (b) ${ }^{7} \mathrm{Be}$, (c) ${ }^{210} \mathrm{~Pb}$ and (d) ${ }^{137} \mathrm{Cs}$ fluxes in the years 1983-1987 determined in two sediment traps moored in Lake Zurich. 
seasonality of atmospheric radionuclide deposition and sediment trap fluxes of ${ }^{10} \mathrm{Be},{ }^{7} \mathrm{Be},{ }^{210} \mathrm{~Pb}$ and particles generally coincide (Figures $1 a$ and $1 b$, Figures $2 b$ and $2 c$, Figure 5).
Lead 210. Fluxes of ${ }^{210} \mathrm{~Pb}$ in the sediment traps are between 50 and $100 \%$ higher in summer than in winter (Table 2) partly due to higher atmospheric radionuclide deposition and partly due to higher particle fluxes in summer. The decrease in
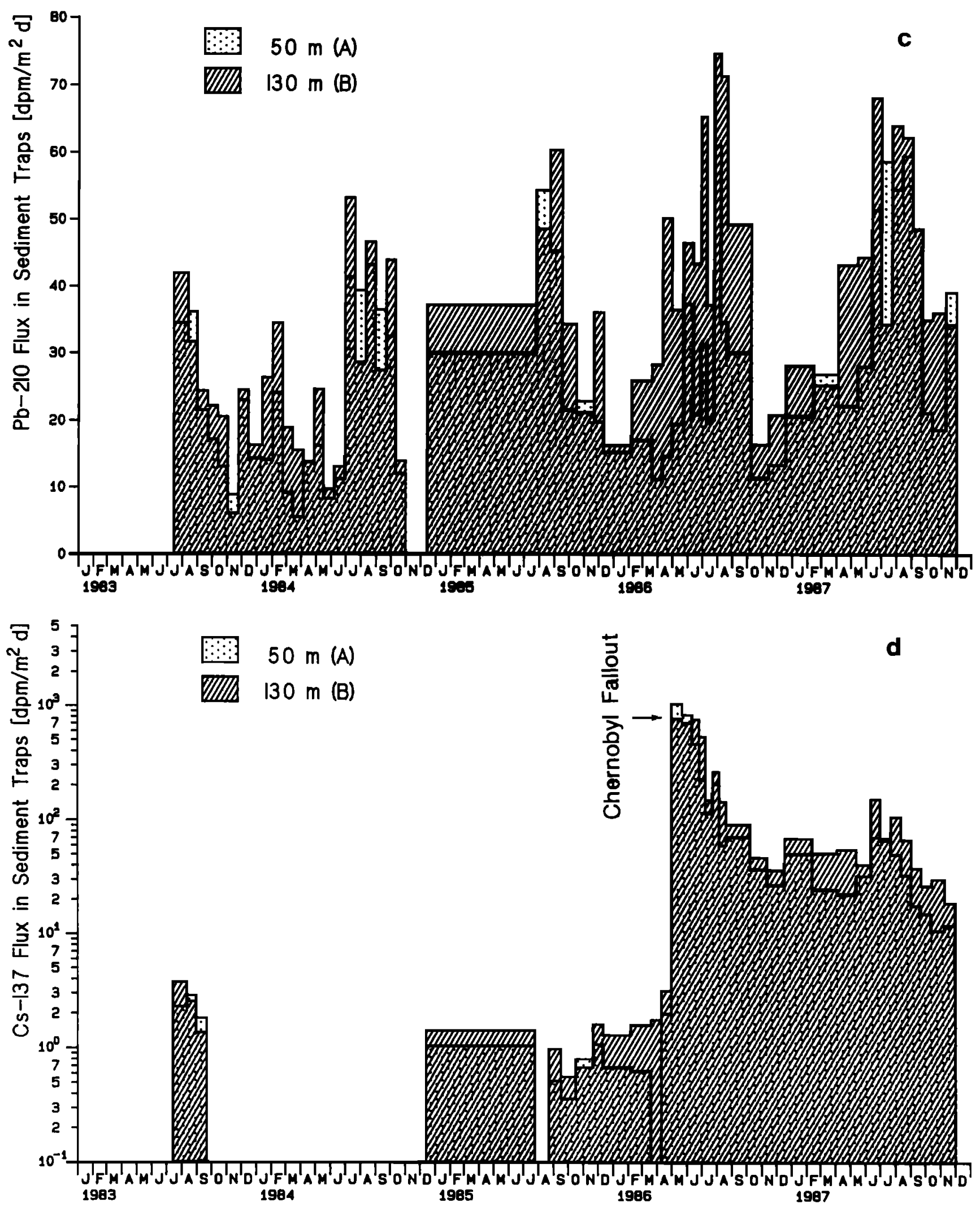

Fig. 2. (continued) 
radionuclide fluxes in winter is, however, less than proportional to the decrease in transfer rates of particles in the lake, indicating higher radionuclide scavenging efficiency during the winter season.

The average fluxes of ${ }^{210} \mathrm{~Pb}$ out of the water column $(0.94$ and $1.22 \mathrm{dpm} \mathrm{cm}^{-2} \mathrm{yr}^{-1}$ at $50 \mathrm{~m}$ and $130 \mathrm{~m}$ depth, respectively, see Table 2) can be compared to the average atmospheric fallout during 1984-1987 (0.83 dpm $\left.\mathrm{cm}^{-2} \mathrm{yr}^{-1}\right)$ (Table 1). Comparison of the summer atmospheric deposition (1.08 $\mathrm{dpm} \mathrm{cm}^{-2} \mathrm{yr}^{-1}$ ) and the sediment trap fluxes (1.18 dpm $\mathrm{cm}^{-2} \mathrm{yr}^{-1}$ at $50 \mathrm{~m}$ ) indicates the quantitative removal of atmospherically delivered ${ }^{210} \mathrm{~Pb}$. During the winter, however, ${ }^{210} \mathrm{~Pb}$ fluxes in sediment trap A $\left(0.73 \mathrm{dpm} \mathrm{cm} \mathrm{yr}^{-1}\right)$ are on average $50 \%$ higher than atmospheric deposition $(0.48 \mathrm{dpm}$ $\mathrm{cm}^{-2} \mathrm{yr}^{-1}$ ). The lead 210 supply from the drainage basin and to minor extent remobilization or resuspension of sediments and recycling into the surface waters may increase the isotope flux in the near-surface sediment trap. However, this extra input of $0.25 \mathrm{dpm} \mathrm{cm}^{-2} \mathrm{yr}^{-1}$ in 0.5 years is $\leq 15 \%$ of the annual average input of ${ }^{210} \mathrm{~Pb}$ to Lake Zurich.

The increase in ${ }^{210} \mathrm{~Pb}$ fluxes with depth is more pronounced in summer $\left(1.18 \mathrm{dpm} \mathrm{cm} \mathrm{cm}^{-2}\right.$ at $50 \mathrm{~m}$ and $1.46 \mathrm{dpm} \mathrm{cm}$ $\mathrm{yr}^{-1}$ at $\left.130 \mathrm{~m}\right)$ than in winter $\left(0.73 \mathrm{dpm} \mathrm{cm} \mathrm{yr}^{-1}\right.$ at $50 \mathrm{~m}$ and $0.85 \mathrm{dpm} \mathrm{cm}^{-2} \mathrm{yr}^{-1}$ at $130 \mathrm{~m}$ ) The larger flux of $210 \mathrm{~Pb}$ in the near-bottom sediment trap during the summer can likely be attributed neither to diffusive remobilization of $210 \mathrm{~Pb}$ into anoxic bottom waters nor to resuspension of underlying sediments. Low current speeds of $\leq 2 \mathrm{~cm} \mathrm{~s}^{-1}$ above sediments were measured during lake stratification in a number of Swiss lakes [Lemmin and Imboden, 1987]. Current speeds of this magnitude are certainly too small to resuspend consolidated sediments. If diffusive remobilization was a relevant process for the enhancement of the ${ }^{210} \mathrm{~Pb}$ flux, the remobilization rate of the iron oxide carrier phase and thus the associated mass flux of iron oxides into the bottom sediment trap should also be significantly increased. In Lake Zurich, iron oxides, however, represent $1-3 \%$ of the total mass flux of settling particles throughout the year [Sigg et al., 1987].

Our results are similar to those of van Hoof and Andren [1989], who found large $210^{\circ b}$ fluxes in a near-bottom sediment trap deployed in Lake Michigan. However, contrary to our observations, resuspension of sediments during winter and spring and the translocation of nearshore particulates during stratification periods were proposed to be the operative mechanisms of radionuclide transport in this large lake.

The comparison of atmospheric and sedimentary fluxes in Lake Zurich indicates that (1) sediment traps at $50 \mathrm{~m}$ depth quantitatively collected the ${ }^{210} \mathrm{~Pb}$ falling through the water column (differences between atmospheric and sediment trap fluxes are likely due to local variations in horizontal transport); (2) atmospheric fallout is, as expected, the only source of $210 \mathrm{~Pb}$ in summer and the dominant source $(-67 \%)$ in winter; and (3) vertical fluxes of $210 \mathrm{~Pb}$ increases with depth in the lake, probably due to horizontal inputs. Fluxes of stable $\mathbf{P b}$ and ${ }^{210} \mathrm{~Pb}$ measured during summer and winter 1983 in both sediment traps are correlated in Figures $3 a$ and $3 b$. Because of the close correlation of ${ }^{210} \mathrm{~Pb}$ and $\mathrm{Pb}$ fluxes $(r=0.60-0.85$, significant at the $99.9 \%$ confidence level, Table 5 ), any information gained through the analysis of the investigation of radionuclide behavior such as that of ${ }^{210} \mathrm{~Pb}$ should also be
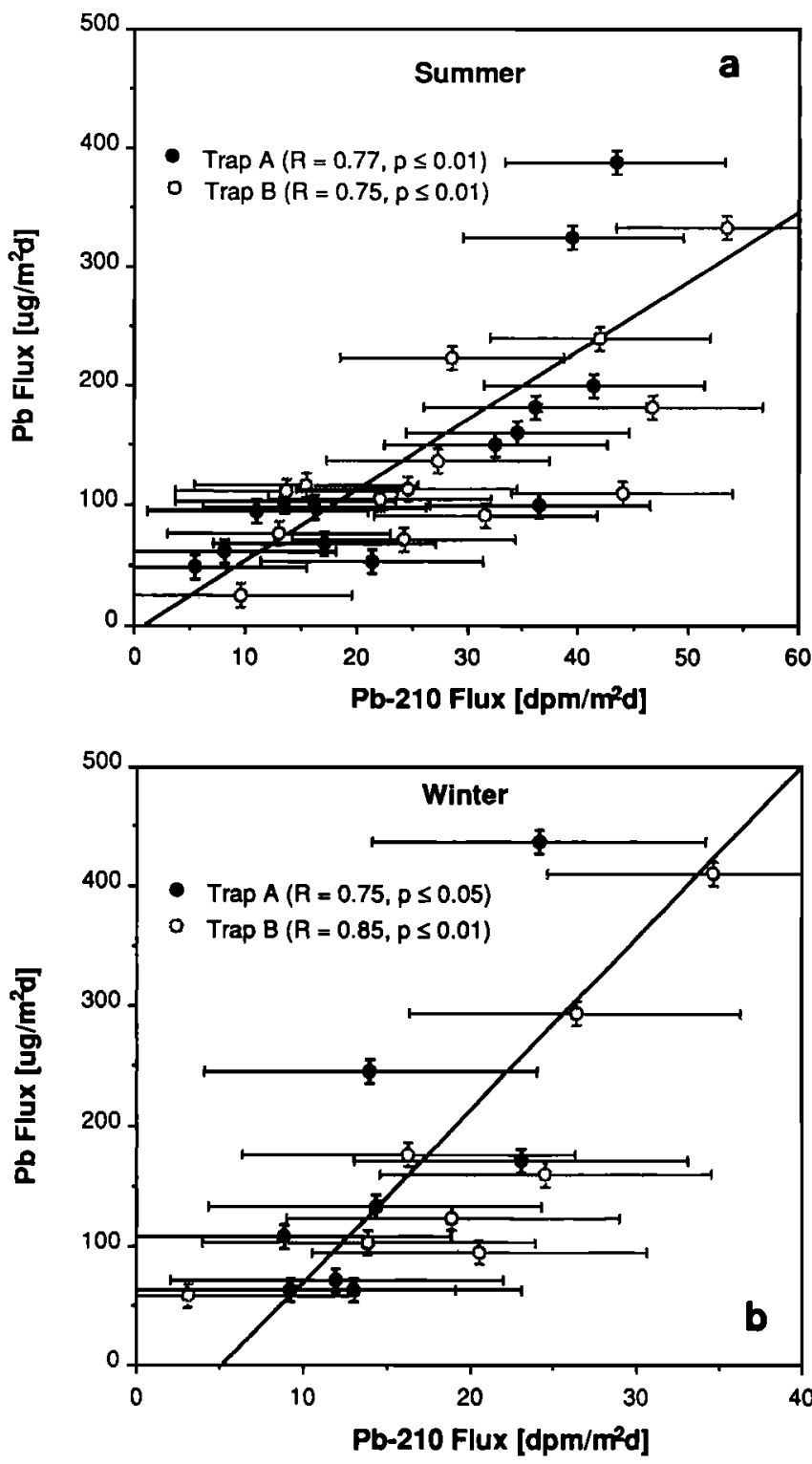

Fig. 3. Correlations of seasonal ${ }^{210} \mathrm{~Pb}$ and $\mathrm{Pb}$ fluxes in sediment traps $A$ and $B$ during $1983 / 1984 . R$ is the correlation coefficient of the linear regression, and 1-p indicates the confidence level for rejecting the hypothesis that the correlation is zero.

directly applicable to selected stable trace metals such as $\mathrm{Pb}$. Even though the chemical speciation of $210 \mathrm{~Pb}$ and stable $\mathrm{Pb}$ in atmospheric aerosols is different, their primary mode of input into surface waters is through rain where both ${ }^{210} \mathrm{~Pb}$ and stable $\mathrm{Pb}$ are largely occurring in the dissolved form. Hence, calculations of removal residence times resulting from the presented multitracer study are most likely good estimates for selected stable trace metals as well.

Beryllium 7 and ${ }^{10}$ Be. The time series of ${ }^{7}$ Be fluxes in sediment traps is presented in Figure $2 b$. Concurrent minima of atmospheric and sediment trap fluxes in winter are a factor of 2 3 lower than the maximum fluxes in summer (Tables 1 and 2). Similar variations in sediment trap fluxes were measured by Dominik et al. [1989] in 1986 in Lake Geneva.

Average ${ }^{7} \mathrm{Be}$ fluxes of $4.90 \mathrm{dpm} \mathrm{cm}^{-2} \mathrm{yr}^{-1}$ measured in the near-surface sediment trap $A$ were considerably lower than atmospheric inputs (16.0 dpm $\mathrm{cm}^{-2} \mathrm{yr}^{-1}$ ) (Tables 1 and 2). 
This observation indicates that most ${ }^{7}$ Be resides in the water column longer than its mean radioactive life of 77 days, thus being removed from the lake mostly by radioactive decay.

Time series of ${ }^{7} \mathrm{Be} /{ }^{210} \mathrm{~Pb}$ ratios in atmospheric deposition, as well as the near-surface and near-bottom sediment traps, are given in Figure 4. The average ${ }^{7} \mathrm{Be} /{ }^{210} \mathrm{~Pb}$ ratio in the atmospheric deposition rates between 1983 and 1987 is 20 .
Even though we assume a relatively large error of $\leq 20 \%$ for the ratios in each time interval, Figure 4 reveals a significant seasonal variation of the ${ }^{7} \mathrm{Be} /{ }^{210} \mathrm{~Pb}$ ratio with a maximum in April caused by the spring maximum of ${ }^{7} \mathrm{Be}$ input from the atmosphere and a minimum in late fall. The seasonal cycle of the ${ }^{7} \mathrm{Be} /{ }^{210} \mathrm{~Pb}$ ratio in atmospheric precipitation is, with some delay of 1-2 months, preserved in sediment traps,
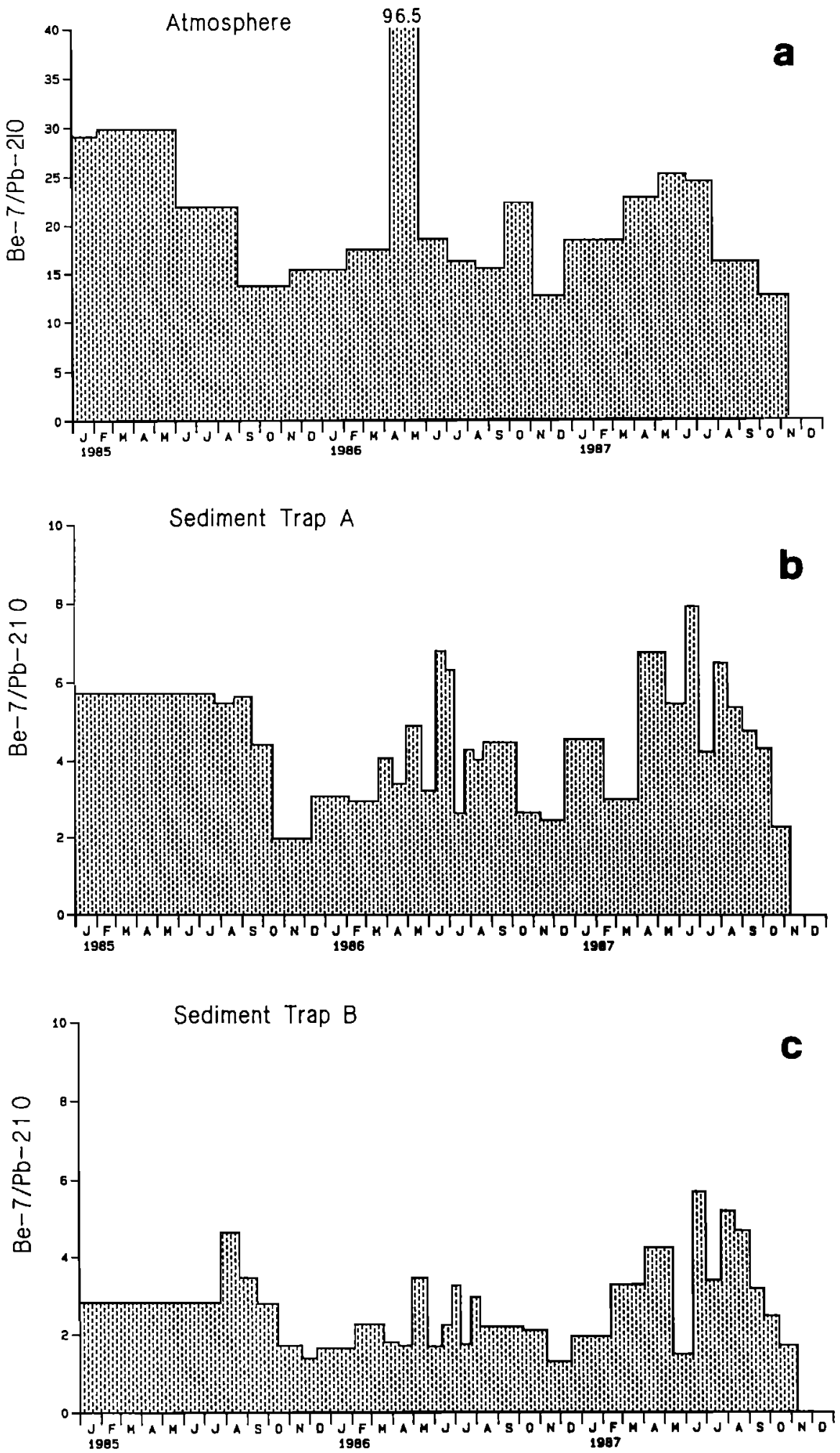

Fig. 4. Ratio of ${ }^{7} \mathrm{Be}$ and ${ }^{210_{\mathrm{Pb}}}$ fluxes measured in (a) atmospheric, (b) sediment trap $\mathrm{A}$ and (c) sediment trap $\mathrm{B}$ collectors. 
indicating that ${ }^{7} \mathrm{Be}$ and ${ }^{210} \mathrm{~Pb}$ are removed from the water column by similar transfer mechanisms, i.e., particle scavenging (Figure 4). Because of the shorter removal residence time of ${ }^{210} \mathrm{~Pb}$ and the decay of ${ }^{7} \mathrm{Be}$ in the water column [Wieland et al., this issue], the ratio of ${ }^{7} \mathrm{Be} /{ }^{210} \mathrm{~Pb}$ is higher in the atmospheric collector than in the sediment traps. Episodic events in particle fluxes with high $210 \mathrm{~Pb}$ and low ${ }^{7}$ Be concentrations are observed in both sediment traps, possibly indicating the lateral input of older fine particles [Wieland et al., this issue].

Beryllium 10 concentrations measured on settling particles are given in Table 3. The time-dependent fluxes of ${ }^{10} \mathrm{Be}$ and the ratio ${ }^{10} \mathrm{Be} /{ }^{7} \mathrm{Be}$ measured on particles which wero collected in 1987 are depicted in Figure 5. The average concentration of ${ }^{10} \mathrm{Be}$ in the $50-\mathrm{m}$ and $130-\mathrm{m}$ sediment traps are $12.2 \pm 3.7 \mathrm{x}$ $10^{7}$ atoms $\mathrm{g}^{-1}$ and $12.2 \pm 2.1 \times 10^{7}$ atoms $\mathrm{g}^{-1}$, respectively.
Sharma et al. [1987] and Bourles et al. [1984] measured ${ }^{10} \mathrm{Be}$ on marine particles and observed ${ }^{10}$ Be concentrations ranging from $20 \times 10^{7}$ atoms $g^{-1}$ in the near-surface traps up to $330 \times$ $10^{7}$ atoms $\mathrm{g}^{-1}$ in the near-bottom sediment traps. In Lake Zurich, ${ }^{10} \mathrm{Be}$ concentrations on settling particles agree well with the average ${ }^{10} \mathrm{Be}$ concentrations $\left(14.7 \pm 2.4 \times 10^{7}\right.$ atoms $\mathrm{g}^{-1}$ ) on particles which were deposited in the uppermost layers of the sediment between 1960 and 1980 (J. Beer, unpublished results, 1990).

Seasonal variations of ${ }^{7} \mathrm{Be}$ and ${ }^{10} \mathrm{Be}$ fluxes strongly correlate in both sediment traps reflecting the similar seasonality of input functions. Time-weighted mean values of ${ }^{7}$ Be and ${ }^{10}$ Be fluxes in the upper trap are $1.9 \times 10^{7}$ atoms m $\mathrm{m}^{-2}$ $\mathrm{d}^{-1}$ and $16.5 \times 10^{7}$ atoms $\mathrm{m}^{-2} \mathrm{~d}^{-1}$, respectively, and $1.6 \times 10^{7}$ atoms $\mathrm{m}^{-2} \mathrm{~d}^{-1}$ and $23.1 \times 10^{7}$ atoms $\mathrm{m}^{-2} \mathrm{~d}^{-1}$ in the near-

TABLE 3a. ${ }^{7}$ Be Concentrations and Fluxes in Sediment Traps

\begin{tabular}{|c|c|c|c|c|c|c|}
\hline Period & $\begin{array}{l}\text { Interval, } \\
\text { days }\end{array}$ & $\begin{array}{c}{ }^{7} \mathbf{B e} \\
\text { in Trap } \mathbf{A}, \\
10^{7} \text { atoms } \mathbf{g}^{-1}\end{array}$ & $\begin{array}{c}{ }^{7} \text { Be Flux } \\
\text { in Trap A, } \\
10^{7} \text { atoms m }{ }^{-2} \mathrm{~d}^{-1}\end{array}$ & $\begin{array}{c}{ }^{7} \mathrm{Be} \\
\text { in Trap B, } \\
10^{7} \text { atoms } \mathrm{g}^{-1}\end{array}$ & $\begin{array}{c}\text { 7 Be Flux } \\
\text { in Trap B, } \\
10^{7} \text { atoms } \mathrm{m}^{-2} \mathrm{~d}^{-1}\end{array}$ & $\begin{array}{l}{ }^{10}{ }_{\mathrm{Be} /} / \mathrm{Be} \\
\text { in Trap } \mathrm{A}\end{array}$ \\
\hline Dec. 17,1986 & 35 & $0.79 \pm 0.04$ & $0.37 \pm 0.04$ & $0.41 \pm 0.02$ & $0.30 \pm 0.03$ & \\
\hline Feb. 12, 1987 & 57 & $0.92 \pm 0.07$ & $1.05 \pm 0.13$ & $0.37 \pm 0.03$ & $0.61 \pm 0.08$ & $11.39 \pm 1.22$ \\
\hline April 3, 1987 & 50 & $0.94 \pm 0.09$ & $0.90 \pm 0.12$ & $0.66 \pm 0.04$ & $0.92 \pm 0.11$ & $14.79 \pm 2.36$ \\
\hline May 13, 1987 & 40 & $0.62 \pm 0.05$ & $1.66 \pm 0.21$ & $0.53 \pm 0.03$ & $2.03 \pm 0.23$ & $8.64 \pm 1.45$ \\
\hline June 11,1987 & 29 & $1.95 \pm 0.13$ & $1.70 \pm 0.20$ & $0.43 \pm 0.03$ & $0.73 \pm 0.09$ & $8.53 \pm 0.95$ \\
\hline July 1,1987 & 20 & $2.51 \pm 0.17$ & $4.54 \pm 0.55$ & $1.52 \pm 0.08$ & $4.27 \pm 0.48$ & $7.30 \pm 0.77$ \\
\hline July 22,1987 & 21 & $3.00 \pm 0.23$ & $2.78 \pm 0.35$ & $1.12 \pm 0.09$ & $1.29 \pm 0.17$ & $8.46 \pm 0.91$ \\
\hline Aug. 12, 1987 & 21 & $1.64 \pm 0.16$ & $3.65 \pm 0.51$ & $1.18 \pm 0.07$ & $3.04 \pm 0.35$ & $7.67 \pm 1.09$ \\
\hline Sept. 2, 1987 & 21 & $0.95 \pm 0.06$ & $4.30 \pm 0.52$ & $1.03 \pm 0.06$ & $3.56 \pm 0.41$ & $7.60 \pm 1.17$ \\
\hline Sept. 23, 1987 & 21 & $0.87 \pm 0.05$ & $2.90 \pm 0.33$ & $0.87 \pm 0.05$ & $2.52 \pm 0.29$ & $5.70 \pm 0.46$ \\
\hline Oct.,14, 1987 & 21 & $0.89 \pm 0.04$ & $1.12 \pm 0.12$ & $0.66 \pm 0.04$ & $1.24 \pm 0.14$ & $9.06 \pm 0.69$ \\
\hline Nov. 10,1987 & 27 & $1.26 \pm 0.05$ & $0.90 \pm 0.10$ & $0.80 \pm 0.04$ & $0.99 \pm 0.11$ & $9.35 \pm 0.62$ \\
\hline Dec.. 2, 1987 & 22 & $1.21 \pm 0.07$ & $1.02 \pm 0.12$ & $0.68 \pm 0.03$ & $0.65 \pm 0.07$ & $10.08 \pm 0.90$ \\
\hline
\end{tabular}

TABLE 3 b. ${ }^{10} \mathrm{Be}$ Concentrations and Fluxes in Sediment Traps

\begin{tabular}{|c|c|c|c|c|c|c|}
\hline Period & Interval, & $\begin{array}{c}10_{\mathrm{Be}} \\
\text { in Trap } A, \\
10^{7} \text { atoms } g^{-1}\end{array}$ & $\begin{array}{c}10_{\text {Be Flux }} \\
\text { in Trap A, } \\
10^{7} \text { atoms } \mathrm{m}^{-2} \mathrm{~d}^{-1}\end{array}$ & $\begin{array}{c}10_{\mathrm{Be}} \\
\text { in Trap B, } \\
10^{7} \text { atoms } \mathrm{g}^{-1}\end{array}$ & $\begin{array}{c}\text { 10 Be Flux } \\
\text { in Trap B, } \\
10^{7} \text { atoms m }{ }^{-2} \mathrm{~d}^{-1}\end{array}$ & $\begin{array}{l}10 \mathrm{Be} / \mathrm{Be} \\
\text { in Trap } \mathrm{B}\end{array}$ \\
\hline Dec. 17, 1986 & 35 & & & & & \\
\hline Feb. 12, 1987 & 57 & $10.52 \pm 0.85$ & $11.92 \pm 1.50$ & $11.42 \pm 0.83$ & $18.91 \pm 2.31$ & $31.05 \pm 3.34$ \\
\hline April 3, 1987 & 50 & $13.94 \pm 1.84$ & $13.37 \pm 2.19$ & $12.27 \pm 0.98$ & $17.00 \pm 2.11$ & $18.52 \pm 1.77$ \\
\hline May 13, 1987 & 40 & $5.37 \pm 0.83$ & $14.38 \pm 2.58$ & $7.12 \pm 1.04$ & $27.19 \pm 4.69$ & $13.38 \pm 2.02$ \\
\hline June 11, 1987 & 29 & $16.61 \pm 1.52$ & $14.51 \pm 1.96$ & $11.59 \pm 2.06$ & $19.68 \pm 3.95$ & $26.78 \pm 5.02$ \\
\hline July 1,1987 & 20 & $18.30 \pm 1.58$ & $33.10 \pm 4.28$ & $16.56 \pm 2.92$ & $46.37 \pm 9.38$ & $10.85 \pm 1.99$ \\
\hline July 22,1987 & 21 & $25.42 \pm 1.96$ & $23.47 \pm 2.93$ & $18.60 \pm 4.44$ & $21.50 \pm 5.52$ & $16.65 \pm 4.16$ \\
\hline Aug. 12,1987 & 21 & $12.64 \pm 1.35$ & $28.04 \pm 4.03$ & $14.12 \pm 2.29$ & $36.20 \pm 6.71$ & $11.91 \pm 1.99$ \\
\hline Sept. 2, 1987 & 21 & $7.21 \pm 1.07$ & $32.70 \pm 5.59$ & $10.55 \pm 0.72$ & $36.42 \pm 4.38$ & $10.22 \pm 0.91$ \\
\hline Sept. 23, 1987 & 21 & $4.96 \pm 0.32$ & $16.55 \pm 1.93$ & $8.63 \pm 0.54$ & $25.00 \pm 2.89$ & $9.93 \pm 0.81$ \\
\hline Oct. 14,1987 & 21 & $8.08 \pm 0.54$ & $10.15 \pm 1.19$ & $8.58 \pm 0.64$ & $16.18 \pm 1.97$ & $13.09 \pm 1.21$ \\
\hline Nov. 10, 1987 & 27 & $11.89 \pm 0.66$ & $8.38 \pm 0.94$ & $12.92 \pm 0.86$ & $16.08 \pm 1.89$ & $16.19 \pm 1.29$ \\
\hline Dec. 2, 1987 & 22 & $12.25 \pm 0.85$ & $10.24 \pm 1.22$ & $14.33 \pm 0.92$ & $13.64 \pm 1.61$ & $20.96 \pm 1.61$ \\
\hline
\end{tabular}



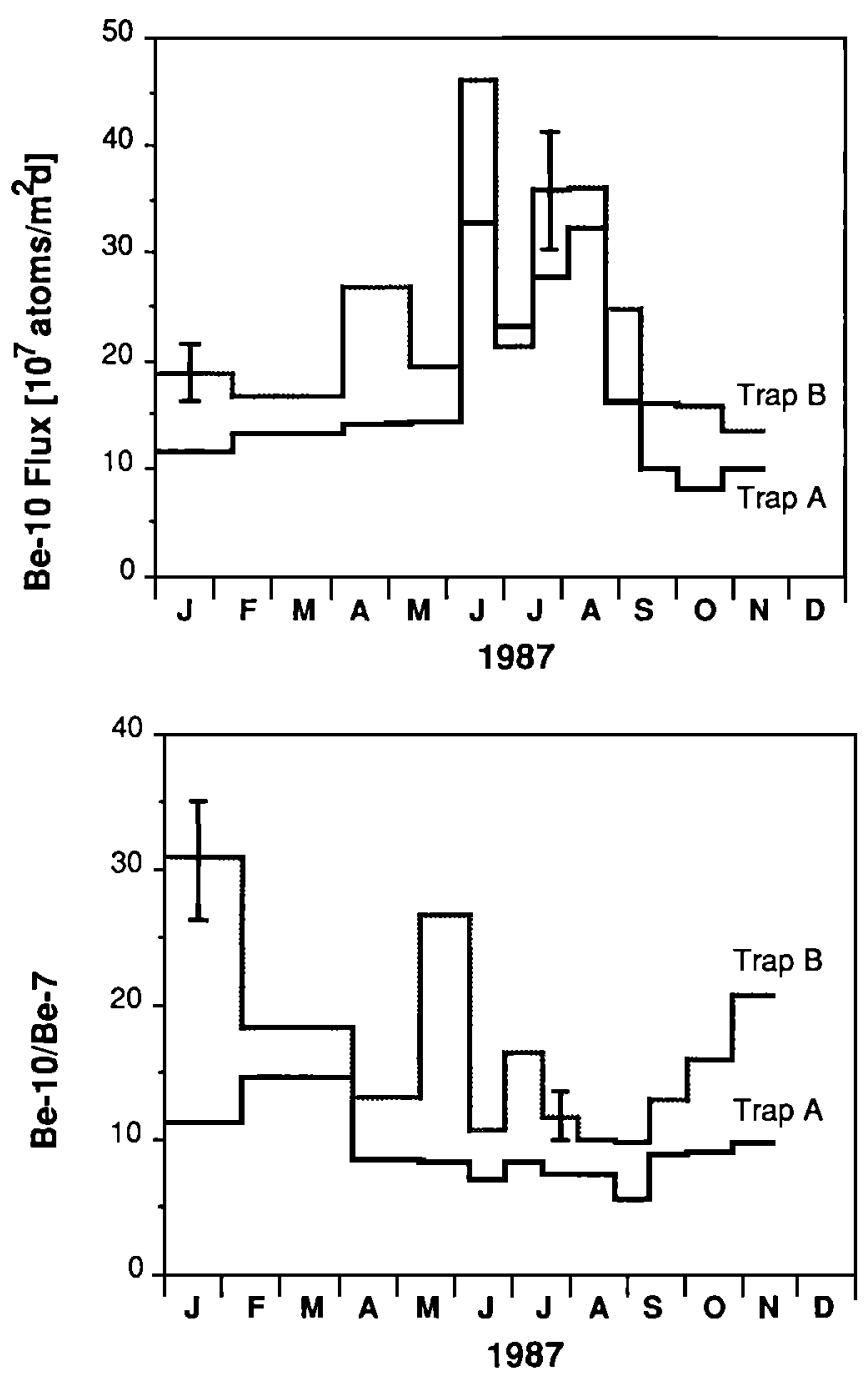

Fig. 5. Fluxes of ${ }^{10} \mathrm{Be}$ in Lake Zurich as well as the ratio ${ }^{10} \mathrm{Be} /{ }^{\prime} \mathrm{Be}$ deposited in sediment traps throughout the year 1987, plotted as a function of time. Errors of $1.65 \sigma$ are given in Table 3.

bottom sediment trap, respectively. The differences in ${ }^{10} \mathrm{Be}$ fluxes between the two traps are significant, i.e., 7.21 $\pm 2.14 \mathrm{x}$ $10^{7}$ atoms $\mathrm{m}^{-2} \mathrm{~d}^{-1}$ (Figure 5). However, ${ }^{10} \mathrm{Be}$ concentrations on settling particles were equal in both sediment traps (Table 3). Hence, the increase in ${ }^{10} \mathrm{Be}$ flux in the lower sediment trap of $40 \%$ is consistent with our finding of higher particle, ${ }^{210} \mathrm{~Pb}$, and ${ }^{137} \mathrm{Cs}$ fluxes at the bottom of Lake Zurich.

Figure 5 also shows the seasonal variation of the ${ }^{10} \mathrm{Be} /{ }^{7} \mathrm{Be}$ ratio in the sediment traps. It further reveals that the average ${ }^{10} \mathrm{Be} /{ }^{7} \mathrm{Be}$ ratios in the sediment traps (trap A: $9.1 \pm 1.5$, trap B: $16.6 \pm 4.2$ ) are increased with respect to atmospheric deposition $(1.86 \pm 0.62)$ most likely due to decay of ${ }^{7} \mathrm{Be}$ in the water column or some supply of long-lived ${ }^{10} \mathrm{Be}$ from the drainage basin. In the near-surface trap, the ratio remains rather constant (winter average: $11.4 \pm 3.4$, summer average: $7.9 \pm$ $0.9)$. In the near-bottom trap, episodic flux events of $10_{\mathrm{Be} \text { - }}$ bearing particles cause two maxima in the ${ }^{10} \mathrm{Be} /{ }^{7} \mathrm{Be}$ ratio (26.8 and 16.7) during summer 1987 (average summer ratio: $14.1 \pm 4.5$ ), illustrating the focusing of particles to the lake bottom. The higher ${ }^{10} \mathrm{Be} / 7^{7} \mathrm{Be}$ ratios in winter (Figure 5) mainly reflect some input of allochthonous or resuspended material as observed in higher ${ }^{210} \mathrm{~Pb}$ fluxes. Contrary to the ${ }^{10} \mathrm{Be} /{ }^{7} \mathrm{Be}$ ratios in the sediment traps, the atmospheric ${ }^{10} \mathrm{Be} /{ }^{7} \mathrm{Be}$ ratios show a maximum in summer (May-July) [Luder, 1986] and a minimum in winter (November-January).

With an initial and constant ${ }^{10} \mathrm{Be} /{ }^{7} \mathrm{Be}$ ratio in atmospheric deposition of 1.9 and the measured ${ }^{10} \mathrm{Be} /{ }^{7} \mathrm{Be}$ ratios in the sediment trap at $50 \mathrm{~m}$ water depth, residence times of ${ }^{7} \mathrm{Be}$ in the lake are estimated to be $84 \pm 7$ days in summer 1987 (MayOctober) and to be $109 \pm 10$ days in winter $1986 / 1987$ (November-April). These values agree well with calculations based on a non steady state model [Wieland et al., this issue]. They also indicate that atmospheric deposition is the main source of ${ }^{10} \mathrm{Be}$ and ${ }^{7} \mathrm{Be}$ in Lake Zurich.

Polonium 210. Polonium 210, which is mainly produced in situ in the water column from $210^{\mathrm{Pb}}$, is expected to be removed more slowly in lakes [Benoit and Hemond, 1986; Talbot and Andren 1984] and in oceans [e.g., Bacon et al., 1976]. The water overlying the settled particles inside the traps was assessed for its radionuclide content in 1986 and 1987. It was found that the enrichment of ${ }^{210}$ Po concentrations was significantly higher than in water outside the sediment traps. However, concentrations of ${ }^{210} \mathrm{~Pb}$ and ${ }^{7} \mathrm{Be}$ were not elevated in water overlying the settled particles, indicating no loss for these nuclides.

While the ${ }^{210} \mathrm{Po} /{ }^{210} \mathrm{~Pb}$ ratio of settling particles was $0.3-$ 0.5 , that value almost doubled in all eight cases investigated in 1986 after it was corrected for extra 210 Po released from the collected particles into the overlying water. When corrected for this artifact, ${ }^{210} \mathrm{Po} / 210_{\mathrm{Pb}}$ ratios average 0.4 to 0.7 (see Table 4). These values can be used to estimate residence times [Wieland et al., this issue]. The appreciable loss of ${ }^{210}$ Po (but not of ${ }^{210} \mathrm{~Pb}$ ) into the overlying water in the sediment traps is likely due to cell lysis since $210 \mathrm{Po}$ is mostly taken up into cell interiors [Fisher et al., 1983]. It also suggests a serious possibility of loss of stable trace elements such as $\mathrm{Zn}, \mathrm{Cd}$, and $\mathrm{Cu}$, as was previously shown for oceanic conditions by Fowler and Knauer [1986]. Their experiments demonstrated that the loss rates of ${ }^{210}$ Po are good indicators for the release of the labile trace elements $\mathrm{Zn}, \mathrm{Cd}$ and $\mathrm{Cu}$, which, incidentally, are also taken up into cell interiors [Fisher et al., 1984]. Therefore, previously reported sediment trap fluxes of these elements in Lake Zurich [Sigg et al., 1987], which lacked any testing for trace element loss, are most likely only lower limits of the true fluxes.

Cesium 137 The time-dependent ${ }^{137}$ Cs fluxes measured in the sediment traps are depicted in Figure $2 d$. Radioactive fallout from the burning Chernobyl reactor increased ${ }^{137} \mathrm{Cs}$ fluxes in the sediment traps from a background value of about $1 \mathrm{dpm} \mathrm{m}^{-2}$ $\mathrm{d}^{-1}$ to $1000 \mathrm{dpm} \mathrm{m}^{-2} \mathrm{~d}^{-1}$ during May 1986. Figure $2 d$ reveals that ${ }^{137} \mathrm{Cs}$ is removed from the water column by settling particles.

Mass balance calculations and the time-dependent inventories of Chernobyl ${ }^{137} \mathrm{Cs}$ in Lake Zurich are discussed by Santschi et al. [1990]. In summer 1986, the ${ }^{137} \mathrm{Cs}$ inventory in the water of Lake Zurich decreased from $27 \pm 3$

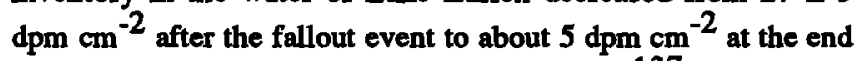
of the stratification period. Time-integrated ${ }^{137} \mathrm{Cs}$ fluxes in

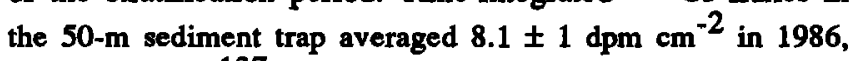
indicating that ${ }^{137} \mathrm{Cs}$ removal by settling particles as shown 


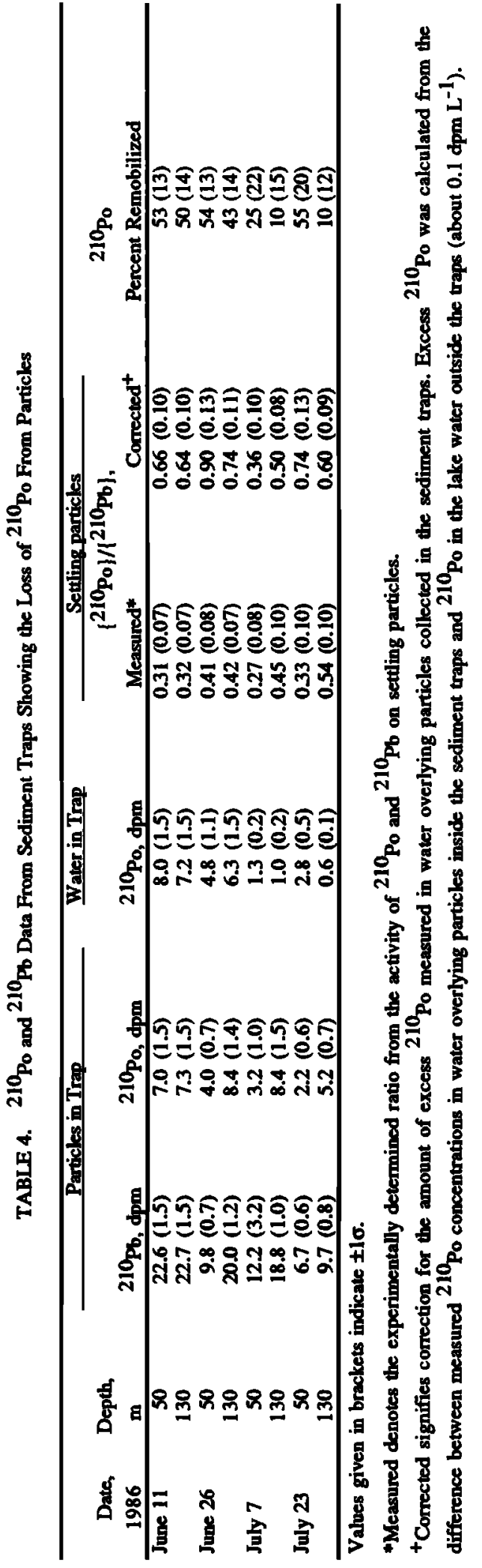

in Figure $2 d$ is a significant process for controlling the isotope activity in the lake. The most striking feature of ${ }^{137} \mathrm{Cs}$ fluxes in sediment traps after the winter of 1986 lake tumover (causing constant ${ }^{137} \mathrm{Cs}$ concentrations in the water) are (1) higher fluxes in the near-bottom sediment trap during summer due to remobilization of ${ }^{137} \mathrm{Cs}$ out of the deepest and seasonally anoxic sediments of the central part of the lake (2) a smaller maximum in ${ }^{137} \mathrm{Cs}$ fluxes during spring and early summer 1987 most likely due to the supply from the drainage basin of allochthonous particulate matter enriched in silicate minerals with high ion exchange capacities for ${ }^{137} \mathrm{Cs}$. The maximum of the ${ }^{137} \mathrm{Cs}$ flux in May-July 1987 (Figure 2d) does not coincide with the maximum in particle fluxes in April and August-September 1987 (Figure 2a). It indicates that organic matter and calcite originating from primary production which make up most of the mass transfer are not primary carrier phases for the removal of ${ }^{137} \mathrm{Cs}$.

The correlation coefficients determined from the linear correlation of the atmospheric fluxes of ${ }^{7} \mathrm{Be}$ and ${ }^{210} \mathrm{~Pb}$ with their sediment trap fluxes, as well as the coeffients calculated from linear regressions between the atmospheric and sediment trap fluxes of ${ }^{7} \mathrm{Be}$ and ${ }^{210} \mathrm{~Pb}$ with rainfall, air, and water temperature and the fluxes of stable lead are summarized in Table 5.

\section{Standing Crops of Radionuclides in the Lake Water}

Results of the determinations of the water column concentration profiles of ${ }^{7} \mathrm{Be}$ are shown in Figure 6. The winter profile (February 1, 1984) reveals deep penetration of this short-lived nuclide to the bottom waters of the lake. Under stratified conditions (August 22 and October 10, 1984), the ${ }^{7} \mathrm{Be}$ activity is restricted to the upper layers of the lake.

Lead 210 activities (not shown) were not very precise (0-50\% errors) but were low throughout the year (Table 1 ) and averaged $1-3 \mathrm{dpm}$ per $100 \mathrm{~L}$, resulting in $210 \mathrm{~Pb}$ standing crops of 5 and $15 \times 10^{-2} \mathrm{dpm} \mathrm{cm}^{-2}$ in wintertime and summertime, respectively.

Cesium 137 profiles in the water column after Chemobyl fallout are published elsewhere [Santschi et al., 1988, 1990]. Cesium 137 activities in surface waters decreased from 12,000 dpm m-3 in June 1986 to $120 \mathrm{dpm} \mathrm{m}^{-3}$ in November 1988, while hypolimnetic ${ }^{137} \mathrm{Cs}$ decreased more slowly from 720 dpm $\mathrm{m}^{-3}$ in November 1986 to about $480 \mathrm{dpm} \mathrm{m}^{-3}$ in November 1988.

\section{Sediment}

Activity profiles of ${ }^{210} \mathrm{~Pb}$ and ${ }^{137} \mathrm{Cs}$ in a core sampled in 1987 at $137 \mathrm{~m}$ water depth are shown in Figure 7. The ${ }^{137} \mathrm{Cs}$ profile reveals two maxima expected from bomb fallout in 1963 and Chernobyl fallout in 1986 . The ${ }^{137} \mathrm{Cs}$ inventory from Chemobyl fallout which was calculated from the ${ }^{134} \mathrm{Cs}$ activity in the core amounts to $5.5 \pm 0.3 \mathrm{dpm} \mathrm{cm}^{-2}$. The sediment inventory is lower than the inventory expected from ${ }^{137} \mathrm{Cs}$ fluxes in the $50-\mathrm{m}$ sediment trap $\left(8.1 \pm 1 \mathrm{dpm} \mathrm{cm}^{-2}\right)$, indicating remobilization of ${ }^{137} \mathrm{Cs}$ from the anoxic sediments of Lake Zurich. Remobilization causes a higher concentration of ${ }^{137} \mathrm{Cs}$ in the seasonally anoxic waters of the hypolimnion as observed in this lake and in Lake Lugano by Santschi et al. [1990].

The ${ }^{210} \mathrm{~Pb}$ inventory in the sediment core was calculated to

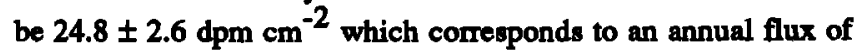




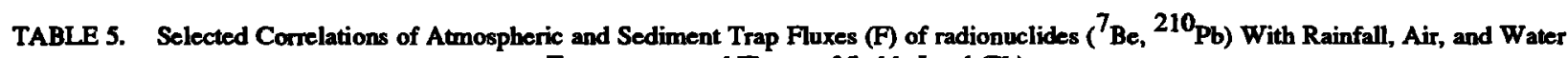
Temperature and Fluxes of Stable Lead (Pb).

\begin{tabular}{|c|c|c|c|c|c|c|}
\hline \multirow[b]{2}{*}{ Correlated Parameters } & \multicolumn{2}{|c|}{ Yearly Data } & \multicolumn{2}{|c|}{ Summer Data } & \multicolumn{2}{|c|}{ Winter Dak } \\
\hline & $r$ & $\mathbf{n}$ & r & $\mathbf{n}$ & $\mathrm{r}$ & $\mathbf{n}$ \\
\hline $\mathrm{F}\left({ }^{7} \mathrm{Be}\right) \mathrm{Atm}_{\mathrm{m}}$ versus air temperature & $0.78 *$ & 23 & 0.58 & 11 & 0.25 & 12 \\
\hline $\mathrm{F}^{\left.210_{\mathrm{Pb}}\right)_{\mathrm{Atm}}}$ versus air temperature & $0.69 *$ & 23 & 0.59 & 11 & 0.18 & 12 \\
\hline $\left.\mathrm{F}^{7}{ }^{7} \mathrm{Be}\right)_{\mathrm{Atm}}$ versus rainfall & 0.33 & 22 & 0.06 & 12 & 0.19 & 11 \\
\hline $\mathrm{F}\left({ }^{\left.210_{\mathrm{Pb}}\right)_{\mathrm{Atm}}}\right.$ versus rainfall & 0.23 & 23 & 0.13 & 12 & 0.07 & 11 \\
\hline $\mathrm{F}$ (particle) versus water temperature & $0.59 *$ & 54 & $0.44^{+}$ & 35 & 0.03 & 19 \\
\hline $\mathrm{F}\left({ }^{7} \mathrm{Be}\right){ }_{\mathrm{STA}}$ versus water temperature & $0.58 *$ & 39 & 0.31 & 25 & 0.37 & 14 \\
\hline $\left.\mathrm{F}^{21{ }^{21}} \mathbf{P b}\right)_{\text {STA }}$ versus water temperature & $0.62 *$ & 54 & $0.59^{*}$ & 35 & 0.01 & 19 \\
\hline $\left.\mathrm{F}^{7}{ }^{7} \mathrm{Be}\right)_{\mathrm{Atm}}$ versus $\mathrm{F}\left({ }^{\left.210_{\mathrm{Pb}}\right)}\right.$ Atm & $0.90^{*}$ & 22 & $0.91^{*}$ & 11 & $0.84 *$ & 11 \\
\hline $\left.\left.\mathrm{F}^{7} \mathrm{Be}\right)_{\mathrm{STA}}{ }^{\text {versus }} \mathrm{F}^{7} \mathrm{Be}\right)_{\mathrm{Atm}}$ & $0.77 *$ & 19 & $0.73^{+}$ & 9 & $0.85^{*}$ & 10 \\
\hline $\left.\mathrm{F}^{210^{20}}\right)_{\text {STA }}$ versus $F\left({ }^{210} \mathrm{~Pb}\right)_{\mathrm{Atm}}$ & $0.73^{*}$ & 23 & $0.70^{+}$ & 11 & $0.69^{+}$ & 12 \\
\hline $\mathrm{F}^{21{ }^{20}} \mathrm{~Pb}_{\text {STA }}{ }^{\text {versus }} \mathrm{F}(\mathrm{Pb})_{\text {STA }}$ & $0.60^{*}$ & 22 & $0.77^{*}$ & 14 & $0.75^{+}$ & 08 \\
\hline 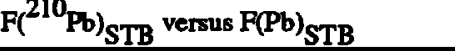 & $0.61 *$ & 22 & $0.75^{*}$ & 14 & $0.85 *$ & 08 \\
\hline
\end{tabular}

The correlation coefficient is denoted as $\mathrm{r}$, and $\mathrm{n}$ is the number of values.

The subscripts are defined as follows: Atm, atmospheric; STA, sediment trap A; STB, sediment trap B.

* Correlations are significant at the $99.9 \%$ confidence level or better.

+ Correlations are significant at the $90 \%$ confidence level or better.
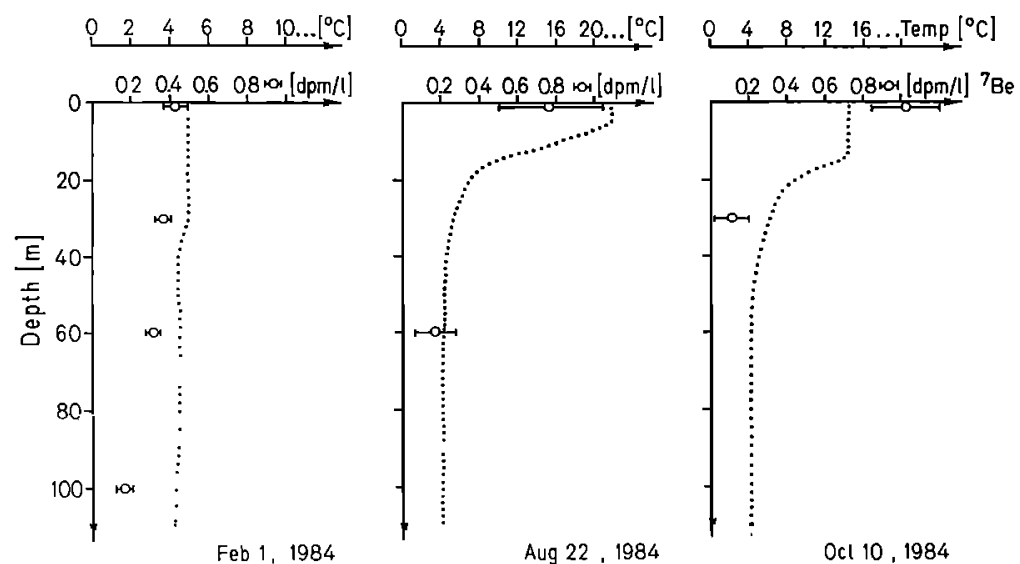

Fig. 6. Activity profiles of ${ }^{7} \mathrm{Be}$ in the water of Lake Zurich.

$0.78 \pm 0.08 \mathrm{dpm} \mathrm{cm}^{-2} \mathrm{yr}^{-1}$. Hence, average atmospheric deposition between 1983 and 1987 (0.83 dpm $\mathrm{cm}^{-2} \mathrm{yr}^{-1}$ ) and time-integrated deposition into the sediments agree, probably by coincidence. Measured fluxes of $210 \mathrm{~Pb}$ at $130 \mathrm{~m}$ water depth, however, averaged $1.22 \mathrm{dpm} \mathrm{m}^{-2} \mathrm{yr}^{-1}$ during 1983-1987 (Table 2). It may indicate some loss of $210 \mathrm{~Pb}$ from settling particles through remobilization in this anoxic layer of water. The sedimentation rate derived from the ${ }^{210} \mathrm{~Pb}$ profile in the sediment core is $0.065 \mathrm{~g} \mathrm{~cm}^{-2} \mathrm{yr}^{-1}$, while the rate derived from the 1963 peak of the ${ }^{137} \mathrm{Cs}$ profile is lower, i.e., $0.052 \mathrm{~g} \mathrm{~cm}^{-2} \mathrm{yr}^{-1}$.

\section{SUMMARY AND CONCLUSIONS}

Temporal variations of input and output fluxes of atmospherically delivered radionuclides $\left({ }^{10} \mathrm{Be},{ }^{7} \mathrm{Be},{ }^{210} \mathrm{~Pb}\right.$, and Chernobyl ${ }^{137} \mathrm{Cs}$ ) have been characterized in order to assess the efficiency of the transfer from the atmosphere to the sediments. Average fluxes of ${ }^{7} \mathrm{Be}$ and ${ }^{210} \mathrm{~Pb}$ from the atmosphere measured in Dübendorf during 1984-1987

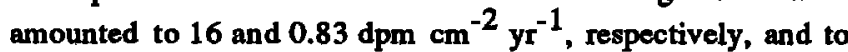
$5.0 \times 10^{7}$ atoms $\mathrm{m}^{-2} \mathrm{~d}^{-1}$ for ${ }^{10} \mathrm{Be}$. The maximum in atmospheric fluxes of ${ }^{7} \mathrm{Be}$ and ${ }^{210_{\mathrm{Pb}}}$ was observed in summer. However, ${ }^{7} \mathrm{Be} /{ }^{210} \mathrm{~Pb}$ ratios showed, as expected, a maximum in springtime.

Input fluxes of ${ }^{7} \mathrm{Be}$ and ${ }^{210} \mathrm{~Pb}$ from the atmosphere into the lake were tightly correlated possibly due to temperature control both of radon emanation from soils and of summertime enhancements of atmospheric removal processes (i.e., thunderstorms).

In Lake Zurich, ${ }^{7} \mathrm{Be}$ and ${ }^{210} \mathrm{~Pb}$ fluxes at $50 \mathrm{~m}$ water depth (sediment trap A) averaged to 4.90 and $0.94 \mathrm{dpm} \mathrm{cm}^{-2} \mathrm{yr}^{-1}$, respectively, and to $6.02 \times 10^{6}$ atoms $\mathrm{cm}^{-2} \mathrm{yr}^{-1}$ for ${ }^{10} \mathrm{Be}$. At $130 \mathrm{~m}$ water depth (sediment trap $B$ ) the average fluxes were $3.99 \mathrm{dpm} \mathrm{cm} \mathrm{cm}^{-2}, 1.22 \mathrm{dpm} \mathrm{cm}^{-2} \mathrm{yr}^{-1}$ and $8.43 \times 10^{6}$ atoms 


\section{Activity [dpm/g]}

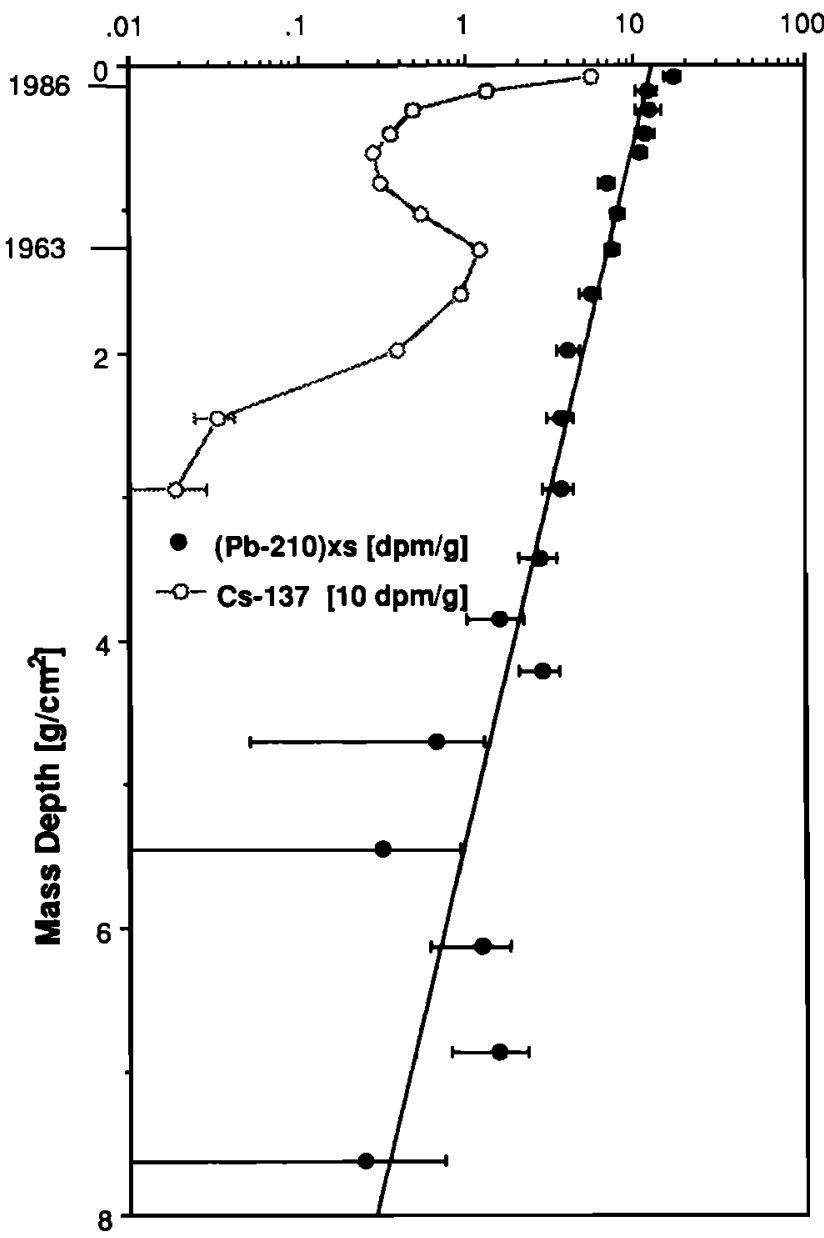

Fig. 7. Activity profiles of ${ }^{210} \mathrm{~Pb}$ and ${ }^{137} \mathrm{Cs}$ in the sediments below the sediment trap array at $137 \mathrm{~m}$ water depth.

$\mathrm{cm}^{-2} \mathrm{yr}^{-1}$ for ${ }^{7} \mathrm{Be},{ }^{210} \mathrm{~Pb}$, and ${ }^{10} \mathrm{Be}$, respectively. This allows three major conclusions.

1. The agreement between atmospheric fluxes of ${ }^{210} \mathrm{~Pb}$ with those measured at $50-\mathrm{m}$ depths indicate that ${ }^{210} \mathrm{~Pb}$ is mainly derived from atmospheric sources.

2. The sediment trap at $50 \mathrm{~m}$ water depth is quantitatively collecting ${ }^{210} \mathrm{~Pb}$ removed from the water.

3. Beryllium 10 and ${ }^{210} \mathrm{~Pb}$ fluxes in the sediment trap at 130 $m$ water depth were, on the average, $20 \%$ higher than fluxes at $50 \mathrm{~m}$ depth due to lateral inputs.

Even though $210^{\mathrm{Pb}}$ was quantitatively collected in these traps, this was not the case for 210 Po. Polonium 210 was found to have been significantly remobilized into the trap solutions, on the average by $50 \%$, during deployment times of 14 to 21 days. Therefore it is likely that previously reported fluxes of labile trace metals such as $\mathrm{Zn}, \mathrm{Cu}$, and $\mathrm{Cd}$ are only lower limits. Radionuclides such as $210 \mathrm{~Pb}$ can be used as physicochemical tracers for stable trace metals such as $\mathbf{P b}$ in order to evaluate removal processes and residence times.

Acknowledgments. Laboratory work was carried out at the Swiss Federal Inatitute of Water Resources and Water Pollution Control (EAWAG). We thank Klaus Farrenkothen for helping with many aspects of the experimental portion of this study. The manuscript has benefited from critical comments on an earlier draft of the manuscript by D. Imboden (EAWAG/ETH, Zurich), M. Baskaran and G. Benoit
(TAMUG) and J. Dominik (Université de Geneve). W. Ela, S. Moran, G. Redden, and two anonymous reviewers kindly provided thoughtful comments on our mansucript. This work was in part supported by EAWAG's teaching and research funds, by the Swiss National Science Foundation, and, at Texas A\&M University, Galveston, Texas, by the Texas Advanced Research Program (grant 4697) and the Texas Institute of Oceanography.

\section{REFerRences}

Appel, I., Das Verhalten von Blei-210 und Polonium-210 im limnischen Milieu am Beispiel des Bodensee-Obersees, Diplomarbeit. Inst. für Umweltphysik, Univ. Heidelberg, 1982.

Bacon, M. P. D. W. Spencer and P. G. Bewers, ${ }^{210} \mathrm{~Pb} /{ }^{226} \mathrm{Ra}$ and $210 \mathrm{Po} /{ }^{210} \mathrm{~Pb}$ disequilibria in seawater and suspended particulate matter, Earth Planet. Sci. Lett., 32, 277-296, 1976.

Barnes, R. S., P. B. Birch, D. E. Spyridakis and W. R. Schell, Changes in the sediment histories of lakes using $210 \mathrm{~Pb}$ as a tracer of sinking particulate matter, in Proceedings of the Intornational Symposium on Isotope Hydrology 1978, vol. 2, Proc. Ser. STIIPUB/493, pp. 875-898, Int. At. Energy, Vienna, 1979.

Barth, M., Blei-210 im Bodensec-Obersee, Diplomarbeit, Inst. für Umweltphysik, Univ. Heidelberg, Heidelberg, 1984.

Beer, J., M. Andree, H. Oeschger, B. Stauffer, C. Stoller, M. Suter, W. Wölfli, and $R$. Finkel, Temporal ${ }^{10} \mathrm{Be}$ variations in ice, Radiocarbon, 25, 269-278, 1983.

Benoit, G., and H. Hemond, A biogeochemical mass balance of ${ }^{210} \mathrm{Po}$ and $210 \mathrm{~Pb}$ in an oligotrophic lake with seasonally anoxic hypolimnion, Geochim. Cosmochim. Acta, 51, 1445-1456, 1986.

Bishop, J. K. B., D. Schupack, R. M. Sherrel, and M. Conte, A multiple-unit large-volume in-situ filtration system for sampling oceanic particulate matter in mesoscale environments, in Mapping stra-tegies in Chemical Oceanography, edited by A. Zirino, Adv. Chem. Ser., 209, 156-175, 1985.

Bloesch, J., and M. Sturm, Settling flux and sinking velocities of particulate phosphorus (PP) and particulate organic carbon (POC) in Lake Zug, Switzerland, in Sediment and Water Interactions, edited by P. G. Sly, Pp. 481-490, Springer-Verlag, New York, 1986.

Bourles, D., G. M. Raisbeck, F. Yiou, J. R. Loiseaux, M. Lieuvin, J. Klein, and $\mathbf{R}$. Middleton, Investigations of possible association of ${ }^{10} \mathrm{Be}$ and ${ }^{26} \mathrm{Al}$ with biogenic matter in the marine environment, Nucl. Instrum. Methods Phys. Res., Sect. B, 5, 365-370, 1984.

Broecker, W. S. and T. K. Peng, Tracers in the Sea, 690 PP., ElDIGIO Press, Palisades, New York, 1982.

Butman, C. A., Sediment trap biases in turbulent flows: Results from a laboratory flume study, J. Mar. Res., 44, 645-693, 1986.

Dasch, J. M., Direct measurements of dry deposition to a polyethylene bucket and surrogate surfaces, Environ. Sci. Technol., 19, 721725, 1985.

Dominik, J., D. Burrus, and J.-P. Vernet, Transport of the environmental radionuclides in an alpine watershed, Earth Planet. Sci. Lett., 84, 165-180, 1987.

Dominik, J., C. Schuler, and P. H. Santschi, Residence times of ${ }^{234} \mathrm{Th}$ and ${ }^{7} \mathrm{Be}$ in Lake Geneva, Earth Planet. Sci. Lett., 93, 345-358, 1989.

Eadie, B. J., and A. Robbins, The role of particulate matter in the movement of contaminants in the Great Lakes, in Sources and Fates of Aquatic Pollutants, edited by R. A. Hites and S. J. Eisenreich, Adv. Chem. Ser. 216, 319-364, 1987.

Fisher, N. S., K. A. Burns, R. D. Cherry, and M. Heyraud, Accumulation and cellular distribution of ${ }^{241} \mathrm{Am}, 210 \mathrm{Po}$ and ${ }^{210} \mathrm{~Pb}$ in two marine algae, Mar. Ecol. Prog. Ser., 11, 233-237, 1983.

Fisher, N. S., M. Bohe, and J.-L. Teyssie, Accumulation and toxicity of $\mathrm{Cd}, \mathrm{Zn}, \mathrm{Ag}$, and $\mathrm{Hg}$ in four marine phytoplankters, Mar. Ecol. Prog. Ser., 18, 201-213, 1984.

Fowler, S. W., and G. A. Knauer, Role of large particles in the transport of elements and organic compounds through the oceanic water column, Prog. Oceanogr., 16, 147-194, 1986.

Hawley, N., J. A. Robbins, and B. J. Eadic, The partitioning of 7 beryllium in fresh water, Geochim. Cosmochim. Acta, 50, 1127 $1131,1986$.

Hesslein, R. H., Whole-lake metal radiotracer movement in fertilized 
basins, Can. J. Fish. Aquat. Sci., 44, 74-82, 1987

Hesslein, R H., W. S. Broecker, and D. W. Schindler, Fates of metal radiotracers added to a whole lake: Sediment-water interactions, Can. J. Fish. Aquat. Sci., 37, 378-386, 1980.

Knauer, G. A., D. M. Karl, J. H. Martin, and C. N. Hunter, In situ effects of selected preservatives on total carbon, nitrogen and metals collected in sediment traps, $J$. Mar. Res., 42, 445-462, 1984.

Kommission zur Ueberwachung der Radioaktivität, Bericht, 25 Jahre Radioakivitdtsüberwachung in der Schweiz, Physikalisches Inst., Univ. Freiburg, Freiburg, Switzerland, 1982.

Lemmin, U., and D. M. Imboden, Dynamics of botton currents in a small lake, Limnol. Oceanogr., 32, 62-75, 1987.

Luder, $P$., ${ }^{10}$ Be und ${ }^{7}$ Be in Niederschlägen und Luftfiltern, Lizentiatsarbeit, Physikalisches Inst., Univ. Bern, Bern, Switzerland, 1986.

Mangini, A., U. Christian, M. Barth, W. Schmitz, and H.H. Stabel, Pathways and residence times of radiotracers in Lake Constance, in Large Lakes: Ecological Structure and Function, edited by M. M. Tilzer and C. Serruya, 691 pp., Springer Verlag, New York, 1990.

Matsunami, T., A. Mizohata, and T. Mamuro, Observations of depositions and atmospheric concentrations of ${ }^{210} \mathrm{~Pb},{ }^{7} \mathrm{Be}$ and ${ }^{137} \mathrm{Cs}$ in Osaka, Annu. Rep. Radiat. Cent. Osaka Prefect., 20, 1-4, 1979.

Murray, J. W., Mechanisms controlling the distribution of trace elements in oceans and lakes, in Sources and Fates of Aquatic Pollutants edited by R. A Hites and S. J. Eisenreich, Adv. Chem. Ser., 216, 153-183, 1987.

Olsen, C. R., I. L. Larsen, P. D. Lowry, N. H. Cutshall, J. F. Todd, G. T. F. Wong, and W. H. Casey, Atmospheric fluxes and marsh-soil inventories of ${ }^{7} \mathrm{Be}$ and ${ }^{210} \mathrm{~Pb}, J$. Geophys. Res., 90(D6), 10487 10495, 1985.

Olsen, C. R., I. L. Larsen, P. D. Lowry, and N. H. Cutshall, Geochemistry and deposition of ${ }^{7} \mathrm{Be}$ in river-estuarine and coastal waters, J. Geophys. "es., 91(C1), 896-908, 1986.

Raisbeck, G. M., F. Yiou, M. Fruneau, J.M. Loiseaux, M. Lieuvin, and J. C. Ravel, Cosmogenic ${ }^{10}{ }_{\mathrm{Be}}{ }^{7} \mathrm{Be}$ as a probe of atmospheric transport processes, Geophys. Res. Lett., 8, 1015-1018, 1981.

Robbins, J. A., and B. J. Eadie, Be-7: A tracer of seasonal particle transport processed in Lake Michigan, Eos Trans. AGU, 63, 957, 1982.

Salomons, W., and U. Förstner, Metals in the Hydrocycle, 349 pp., Springer-Verlag, New York,1984.

Santschi, P. H., Y.-H. Li, and J. Bell, Natural radionuclides in Narragansett Bay, Earth Planet. Sci. Lett., 45, 201-213, 1979.

Santschi, P. H., Y.-H. Li, J. Bell, R. M. Trier, and K. Kawtaluk Plutonium in the coastal marine environment, Earth Planet. Sci. Lett., 51, 248-265, 1980.

Santschi, P. H., U. P. Nyffeler, R. F. Anderson, S. L. Schiff, and P. OHara, Response of radioactive trace metals to acid-base titrations in controlled experimental ecosystems: Evaluation of transport parameters for application to wholo lake radiotracer experiments, Can. J. Fish. Aquat. Sci., 43, 60-77, 1986.

Santschi, P. H., C. Schuler, and M. Sturm, Natural and Chernobyl radionuclides as tracers of particle settling and resuspension in Lake Zurich, Switzerland, Terra Cognita, 7(2-3), 185, 1987.

Santschi, P. H., S. Bollhalder, K. Farrenkothen, A. Lueck, S. Zingg, and $M$. Sturm, Chemobyl radionuclides in the environment: Tracers for the tight coupling of atmospheric, terrestrial and aquatic geochemical processes, Environ. Sci. Technol., 22, 510-516, 1988.
Santschi, P. H., Use of radionuclides in the study of contaminant cycling processes, Hydrobiologia, 176/177, 307-320, 1989.

Santschi, P. H., and B. D. Honeyman, Radionuclides in aquatic environ-ments, Radiat. Phys. Chem., 34 (2). 213-240, 1989.

Santschi, P. H., S. Bollhalder, S. Zingg, A. Lueck, and K. Farrenkothen, The self-cleaning capacity of surface waters after radioactive fallout: Evidence from European waters after Chernobyl, 1986-1988, Environ. Sci. Technol., 24, 519-527, 1990.

Schiff, S. L., K. G. Beaty, and R. F. Anderson, ${ }^{7}$ Be mass balance of two small Precambrian shield lakes, Eos Trans. AGU, 64, 1030, 1983.

Schuler, C., P. H. Santschi, and M. Sturm, Natural radionuclides as tracers for geochemical transport processes in Lake Zurich, Switzerland, paper presented at the Symposium on Functional and Structural Properties of Large Lakes, Constance, Weat Germany, Sept. 13-18, 1987.

Sharma, P., R. Maharnah, W. S. Moore, T. L. Ku, and J. R. Southon, Transport of ${ }^{10} \mathrm{Be}$ and ${ }^{9} \mathrm{Be}$ in the ocean, Earth Planet. Sci. Lett., 86, 69-76, 1987.

Sigg, L., M. Sturm, and D. Kistler, Vertical transport of heavy metals by settling particles in Lake Zurich, Limnol. Oceanogr., 32, 112 $130,1987$.

Stiller, M., and D. M. Imboden, ${ }^{210} \mathrm{~Pb}$ in Lake Kinneret waters and sediments: Residence times and fluxes, in Sediment and Water Interactions, edived by P. O. Sly, pp. 501-511, Springer-Verlag, New York, 1986.

Suter, M., R. Balzer, G. Bonani, H. J. Hofmann, E. Morenzoni, M. Nessi, W. Wolfli, M. Andree, J. Beer, and H. Oeschger, Precision measurements of ${ }^{14} \mathrm{C}$ in AMS - some results and prospects, $\mathrm{NuCl}$. Instrum. Methods Phys. Res., Sect. B, S, 117-122, 1984.

Talbot, R. W., and A. W. Andren, Seasonal variation of ${ }^{210} \mathrm{~Pb}$ and $210_{\text {Po }}$ concentrations in an oligotrophic lake, Geochim. Cosmochim. Acta, 48, 2053-2063, 1984.

Turekian, K. K., L. K. Benninger, and E. P. Dion, ${ }^{7}$ Be and ${ }^{210_{\mathrm{Pb}} \text { total }}$ deposition fluxes at New Haven, Connecticut, and at Bermuda, $J$. Geophys. Res., 88(C9), 5411-5415, 1983.

Van Hoof, P. L., and A. W. Andren, Partitioning and transport of $210^{\mathrm{Pb}}$ in Lake Michigan, J. Great Lakes Res., 15(3), 498-509, 1989.

Wieland, E., P. H. Santschi, and J. Beer, A multitracer study of radionuclides in Lake Zurich, Switzerland, 2, Residence times, removal processes, and sediment focusing, $J$. Geophys. Res., this issue.

J. Beer, S. Bollhalder, A. Lueck, and M. Sturm, Institut fur Mittel-energiephysik, ETH Honggerberg, 8093 Zurich, Switzerland. G. Bonani, H.J. Hofmann, and W. Wolfli, Paul Scherrer Institut,

5232 Villigen PSI, Switzerland. P.H. Santschi, Department of Marine Sciences, Texas A \& M University, Galveston, TX 77553-1675.

C. Schuler and M. Suter, Eidgenossische Anstalt fur Wasser, Abwasser und Gewasserschutz, 8600 Dubendorf, Switzerland. E. Wieland, Department of Civil Engineering, Stanford University, Stanford, CA 94305-4002.

(Received June 21, 1990;

revised May 30, 1991;

accepted December 28, 1990.) 